\title{
The Groundwater Geochemistry and the Human Health Risk Assessment of Drinking Water in an Area with a High Prevalence of Chronic Kidney Disease of Unknown Etiology (CKDu), Sri Lanka
}

\author{
W. S. M. Botheju $\mathbb{D}^{1,2}$ J. A. Liyanage $\mathbb{i D}^{2}$ and S. D. P. Kannangara $\mathbb{i D}^{3}$ \\ ${ }^{1}$ Department of Indigenous Medical Resources, Gampaha Wickramarachchi University of Indigenous Medicine, \\ Yakkala, Sri Lanka \\ ${ }^{2}$ Department of Chemistry, University of Kelaniya, Colombo, Sri Lanka \\ ${ }^{3}$ Department of Plant and Molecular Biology, University of Kelaniya, Colombo, Sri Lanka
}

Correspondence should be addressed to W. S. M. Botheju; 2017_botheju@kln.ac.lk

Received 13 May 2021; Revised 18 August 2021; Accepted 1 October 2021; Published 21 October 2021

Academic Editor: Jose Corchado

Copyright (c) 2021 W. S. M. Botheju et al. This is an open access article distributed under the Creative Commons Attribution License, which permits unrestricted use, distribution, and reproduction in any medium, provided the original work is properly cited.

\begin{abstract}
Chronic kidney disease of unknown etiology $(\mathrm{CKDu})$ has become an alarming health issue in Sri Lanka. The disease is more notable among farming communities and people who consume groundwater as their main source of drinking water. To assess the possible links between drinking water chemistry and expansion of $\mathrm{CKDu}$, the study was compared with hydrogeochemical data of drinking water sources in a CKDu prevalent area (Girandurukotte GND, Badulla District) and a reference area (Dambethalawa GND, Ampara District) in Sri Lanka. Based on the results, nephrotoxic heavy metal ( $\mathrm{Cd}, \mathrm{Cr}, \mathrm{Pb}$, and As) concentrations were significantly higher in the CKDu prevalent site than the reference area, compromised the harmful consequences to the people in the CKDu hotspot. Results of the inverse distance weighted (IDW) interpolation tool indicated the nephrotoxic heavy metals contents including $\mathrm{Cd}, \mathrm{Pb}$, As, and $\mathrm{Cr}$ in $\mathrm{CKDu}$ hotspot were changed in the ranges of 9.78-187.25 $\mu \mathrm{g} / \mathrm{L}, 0.08-0.66 \mu \mathrm{g} / \mathrm{L}$, $20.76-103.30 \mu \mathrm{g} / \mathrm{L}$, and $0.03-0.34 \mu \mathrm{g} / \mathrm{L}$. The random distribution patterns were shown by the result in Moran's index values. Noteworthy, the results have emphasized a strong association between fluoride and water hardness. The frequency of occurrence above the threshold limit of fluoride was $28 \%$ in non-CKDu water samples, while $81 \%$ in CKDu prevalent sites. The hardness values in the CKDu prevalent site indicated "moderately hard water," while the non-CKDu area indicated the "soft water." Furthermore, this paper quantified overall water quality and heavy metal contamination and assessed the human health risks associated with drinking water. According to the results of the water quality index, $90 \%$ of the samples in the CKDu prevalent area were classified as "poor water" and "very poor water" for drinking purposes, while $73.33 \%$ of the samples in the non-CKDu area were "good" and "excellent" for drinking usage. Calculated chronic daily intake $\left(\mathrm{CDI}_{\text {oral }}\right)$ and hazard quotient $\left(\mathrm{HQ}_{\text {oral }}\right)$ of nephrotoxicants were higher in CKDu hotspot than the non-CKDu site. Besides, the hazard index (HI) values obtained for the CKDu prevalent area exceeding the acceptable limit $(\mathrm{HI}=1)$ indicated potential health risks to the people in those areas. This study suggests that long-term exposure to nephrotoxic heavy metals, water hardness, and fluoride present in drinking water may threaten human health and affect kidney functions. Therefore, regular monitoring and better management of water supplies in CKDu prevalent areas are essential to determine the contamination load and reduce the health impacts due to excessive and longterm exposure to the nephrotoxicants.
\end{abstract}

\section{Introduction}

$\mathrm{CKDu}$ is a new type of nephropathy reported in several countries over the last few decades $[1,2]$, and the root causes for this disease are still in question and research. Although
CKDu presents as kidney disease in patients, they do not show common causative factors such as diabetes, hypertension, primary glomerularnephritisis, or other known etiologies [3-5]. Due to the increase in the number of patients and disease-related deaths that have reached epidemic 
proportions, $\mathrm{CKDu}$ becomes one of the most risk-bearing health issues. This is a burning problem throughout the world due to its mysterious nature [6-8]. CKDu is defined as the occurrence of chronic kidney disease (CKD) without a known underlying cause $[7,9,10]$. Although various studies have been conducted to postulate the potential causes for $\mathrm{CKDu}$, no specific source or causative factor has been identified for this noncommunicable disease with a multifactorial origin [11]. Therefore, environmental toxins related to the drinking water belong to prime suspected causative factors for $\mathrm{CKDu}$ as apparent causative factors and effect relationships remain unknown [4, 12-15].

$\mathrm{CKDu}$ is mostly distributed in the countries near the equator and has flat lands with low elevations, prolonged droughts, and low economic development with low healthcare facilities, clean water, and safe sanitation. People in $\mathrm{CKDu}$-affected countries face global warming, increasing temperature, El Niño effects, and prolonged dry spells $[11,16,17]$. This incidence is observed mainly in developing countries where agriculture is the primary income source [18]. El-Salvador, Guatemala, Mexico, Nicaragua, Bulgaria, Croatia, Serbia, Egypt, India, and Sri Lanka are major geographic hot spots of CKDu with more than 50,000 patients with late-stage kidney disease $[4,13,19-25]$. CKDu is now a significant public health problem due to its insidious nature and irreversible progression. It is well recognized that the major effect of the disease is the permanent loss of kidney function over time, and due to the nature of the unknown etiology of this disease, it has been named CKD of unknown etiology or $\mathrm{CKDu}$ [26].

According to the WHO records, in 2009, approximately 5,000 patients had been treated for chronic kidney disease in Sri Lanka, and in 2012, the number of patients has increased to 8,000 [27]. CKDu outbreak and the prevalence among the people in Sri Lanka were first reported in the early 1990s [7]. Afterward, it was endemic to some areas in the country where agriculture is the main occupation and the income of the people $[8,20,28]$. According to the reported health issues, the disease prevalence ranges from $2 \%$ to $3 \%$ [4] and from $15 \%$ to $23 \%$ [21, 29-31]. As described by Wickramarathna et al. [20], approximately $70 \%$ of CKDu cases are diagnosed among the chronic kidney disease (CKD) points in the dry zone of Sri Lanka, and it has been reported among residents between 30 years and 60 years $[4,12,14,21,32]$. The affected areas lie in the North Central Province; northern parts of the Uva Province, including Mahiyanganaya and Girandurukotte; and some parts of the NorthWestern Province comprising Nikawewa in Sri Lanka that are belong to the dry zone of the country $[12,33]$. Together, these three areas can be introduced as unique geographical terrain named the North Central Region (NCR) of Sri Lanka $[34,35]$.

In Sri Lanka, CKDu is one of the very aggressive causes with the absence of exact responsible reason. Notably, this is very common among men (proportion of male:female is $3: 1$ ) who are around the age of 40-60 years, and the majority of them are farmers or agricultural farmers [4, 27, 34, 36, 37]. The mean age of the CKDu-affected patients was 56.7 years and 54.2 years for male and female farmers in 2007, respectively, while 45.5 years for males and 47.4 years for females in 2012 [38, 39]. Therefore, CKDu has become a major health burden in the country that attacks the social and economic aspects of the people in Sri Lanka. In medical terms of the $\mathrm{CKDu}$, renal glomeruli are affected, and renal tubules are damaged early in the disease. The late features of the diseases are peripheral edema and hypertension $[12,14,20,40]$. An early clinical sign of CKDu is urinealbumin excretion above standard thresholds. This disease also shows similarities to Balkan endemic nephropathy $[41,42]$. Although various causative factors have been proposed for the etiology of CKDu by different studies, there are no adequate explanations for the cause of CKDu. There are various potential sources and hypotheses that lead to $\mathrm{CKDu}$, such as water contaminations, geo-accumulation issues, excessive usage of agrochemicals, unidentified biological toxins, pesticide residues, nephrotoxic heavy metal contaminations, high levels of fluorides, water hardness, use of low-quality utensils in food preparations, exposure to direct sunlight, consequent heat stress with recurrent dehydration, and some other environmental factors $[13,33,43-46]$. The relationship between the water hardness and the occurrence of CKDu has been reported in many earlier studies, together with some other factors such as excess levels of fluorides. Hard water mainly occurs in the presence of calcium, magnesium, strontium, and iron together with carbonate, bicarbonate, sulfate, and chloride anions [20, 47-49]. Interestingly, most CKDu prevailing areas overlap with high fluoride zones in groundwater [12]. As described by World Health Organization [50], Sri Lanka is one of the countries where the fluoride content in water resources is higher, reaching the maximum standard value of $0.6 \mathrm{mg} / \mathrm{L}$. This shows that the quality of drinking water requires closer investigation in exploring the onset of $\mathrm{CKDu}$ root since the kidneys filter around $180 \mathrm{~L}$ of fluid every day and as they are liquid intensive organs. Furthermore, excessive amounts of environmental toxicants containing herbicides, pesticides, and fertilizers are significant contributors to water contamination in agricultural regions, especially in developing countries, including Sri Lanka $[11,51]$.

In Sri Lanka, most of the population in dry zone regions use shallow well water, deep well water, and tube wells compared to those using natural spring water $[20,33]$. Earlier studies show that the villagers in CKDu-affected areas use groundwater from aquifers in high-grade metamorphic regolith, mainly unbound weathered or partly weathered loose rocks or soils [12]. More than $87 \%$ of the people in the CKDu prevalent areas of Sri Lanka consume groundwater that bringing out a form from shallow wells about $10 \mathrm{~m}-60 \mathrm{~m}$ depth $[52,53]$. Therefore, earlier studies revealed that people who drink well water are more vulnerable to those who use water from natural springs, rainwater, and surface waters from rivers and reservoirs $[12,54]$. Furthermore, there are possible effects of water with excessive levels of ions that are combined with kidneys via Hofmeister-type protein denaturation mechanisms $[12,42,55]$. The health of a population depends on the geochemistry of the terrain. The severe depletion of toxic 
elements or accumulation of the elements in toxic levels can be seen in tropical regions as the terrains of these areas are highly subjected to severe droughts and extreme rainfall conditions $[20,48,53]$. There are severe depletions of elements or excess levels of some elements such as fluoride, iodine, and selenium due to the leaching, transferring, and concentration in the environment, and they enhance various chronic and endemic diseases [56]. In addition, heterogeneous distribution of chemical species in the geo-environment can occur in tropical environmental conditions such as high temperatures, high rainfall alternating with very dry spells, element fractionation during rock weathering, and soil formation [4, 49]. Furthermore, it is speculated that chronic exposure to heavy metals causes various human disorders comprising renal damages such as $\mathrm{CKDu}$ [11, 57-59]. Compared to organic pollutants, heavy metals are high-density non-biodegradable metallic elements with long-lasting toxic effects. The transfer of these heavy metals to the environment has occurred through various pathways [60-62]. Due to their bioaccumulation ability and high toxicity, heavy metals are classified as severe environmental pollutants [63]. Some early studies reported that most of the water samples collected from CKDu prevalence areas show low levels of heavy metal concentrations, which are not exceeded the safe upper limits $[5,13,14,64]$. In contrast, some studies reported varying low levels of heavy metals in water resources in CKDu prevalent areas [11, 43, 65]. Although the quantities of heavy metals in some water samples are lower than the safety levels, epidemiological studies have indicated an interrelation between exposure to various nephrotoxic heavy metals such as cadmium, lead, arsenic, and chromium and the development of acute or chronic renal failure [66]. Moreover, research findings indicated that exposure to heavy metals at higher concentrations for shorter periods (acute) or lower concentrations for more extended periods (chronic) could cause renal failures $[11,58,67-69]$. Furthermore, the chemical form of the heavy metal, the dose and the concentration, and intermetal and other chemical interactions are also causing chronic kidney diseases $[66,70]$. The combination of these heavy metals with other nephrontoxins in prevalent areas with chronic dehydration and oxidative stress causes CKDu. They lead to the development of CKDu even at lower concentrations of probable individual agents such as nephrotoxic heavy metals $[11,71,72]$. Therefore, it is essential to determine the current state of water in the study area and identify the spatial patterns and potential sources of the nephrotoxic heavy metals and other risk factors. Among various types of researches regarding the onset of CKDu in Sri Lanka, only a few studies have focused on the spatial distribution of different toxic substances. Therefore, investigating the environmental toxicant levels and distribution is much needed to determine the ecological toxicant pollution status in $\mathrm{CKDu}$ highly prevalent areas.

Moreover, health risk assessment is an essential tool for understanding the nephrotoxic elements in water and their health impacts in a sampling area. Based on the water quality standards and the health risk benchmarks, the potential impact of water contaminations can be quantified [73-75].
The main purpose of risk evaluation is to minimize the health risks associated with using contaminated drinking water in CKDu prevalent areas. Pollution indices, including heavy metal evaluation index (HEI), heavy metal pollution index (HPI), and other indices such as water quality index (WQI), chronic daily intake (CDI), hazard quotients (HQ), and hazard index (HI), can be used in an attempt to categorize the water quality and health risks related with contaminated water resources $[74,76]$. The reported health risk assessment of the nephrotoxic heavy metals and other risk factors in $\mathrm{CKDu}$ prevalent areas of Sri Lanka are less. Therefore, this study is efficacious in assessing the various human health risks associated with the use of water resources in the study area. The main objectives of the study were to (1) determine the major and trace ion constituents (nephrotoxic elements) in drinking water as possible causative factors for the onset of $\mathrm{CKDu}$, (2) determine the heavy metal pollution levels and indices in the study area, (3) interpolate the spatial distribution of nephrotoxic heavy metals using geostatistical tools, and (4) assess the interrelationship between the water quality and health risk parameters using the comparative analysis of results of disease prevalent area and the reference area. It is expected that the findings of this investigation would have implications for the thousands of people living in CKDu prevalent areas in Sri Lanka, and this will provide important insights into the monitoring and management of drinking water resources in Girandurukotte GND, Badulla District in Sri Lanka for human health and the environment.

\section{Materials and Methodology}

2.1. Study Area Description. The present investigation was carried out in Girandurukotte GND, a CKDu endemic area, based on the information obtained from the Ministry of Health, Sri Lanka. Girandurukotte GND is located in the Badulla district in the Uva province in Sri Lanka, which belongs to the dry zone low country region. Annual rainfall is around $1,800 \mathrm{~mm}$, mainly from October to December, and the average temperature is about $30^{\circ} \mathrm{C} \quad\left(29^{\circ} \mathrm{C}-30^{\circ} \mathrm{C}\right)$. Groundwater, surface water, and rainwater are the primary drinking water sources in Girandurukotte GND. In Girandurukotte, farming is the primary occupation of the majority of the population. This area has been identified as a hotspot of the onset of CKDu recently, which is come out like a kidney disease that is not related to any identified risk factors, including hypertension, diabetes, and glomerulonephritis $[30,77,78]$. The study area comes across the right bank of the River Mahaweli. The sampling locations in Girandurukotte GND are shown in Figure 1(a).

Geologically, Girandurukotte is underlined by highgrade metamorphic rocks of the Precambrian age. Quartzite, marble, and varieties of gneisses, including biotite gneisses, garnet-biotite-hornblende gneisses, and calcgneiss, are the most abundant metasedimentary suites in the Girandurukotte study area. Besides meta-igneous suits of granodioritic gneiss, varieties of charnockites, orthopyroxene-bearing gneisses, are highly spread in the study area [20, 78]. A majority of households consume groundwater from regolith 


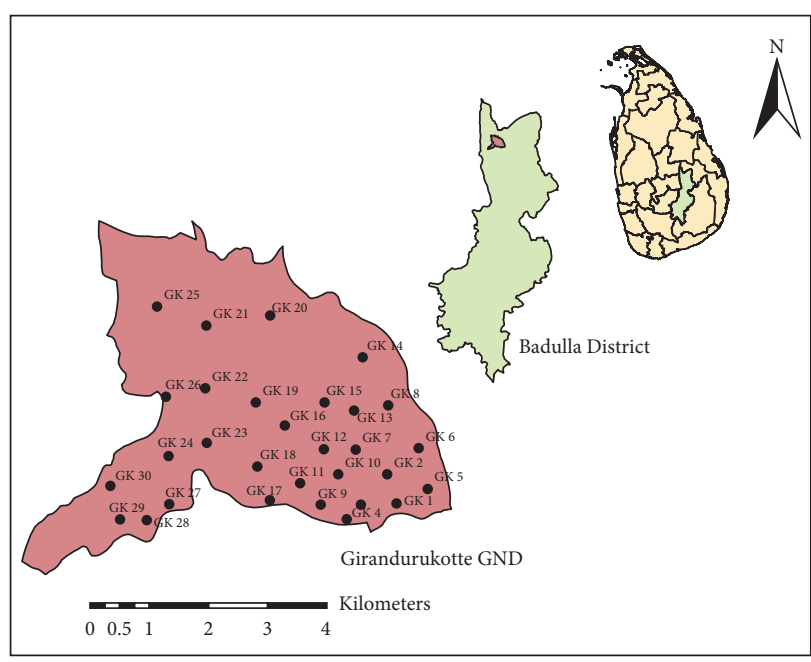

(a)

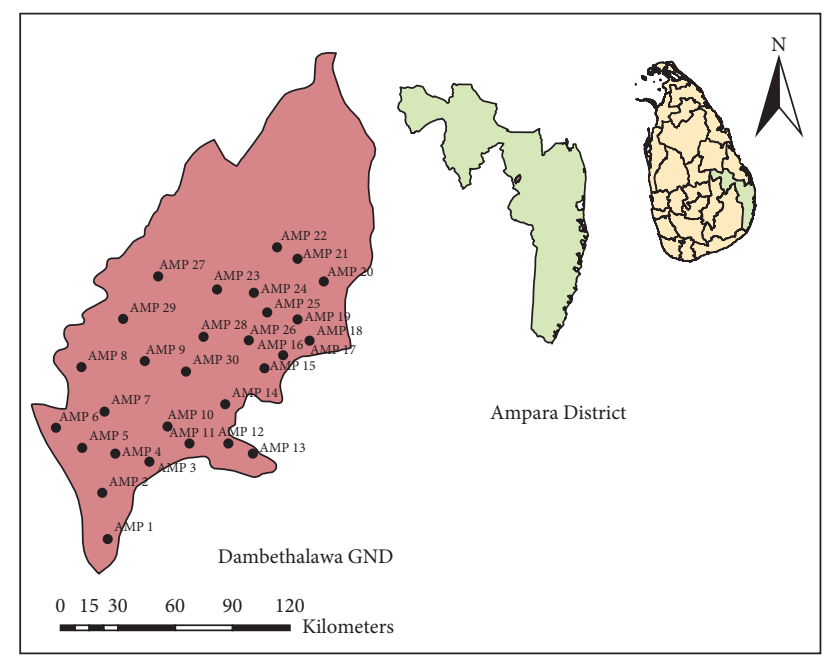

(b)

FIgURE 1: The distribution of the sampling points in the CKDu prevalent area: (a) Girandurukotte GND, Badulla District, and reference area and (b) Dambethalawa GND, Ampara District, Sri Lanka.

aquifers in the study area. Most of the drinking water wells penetrate the fluvial sediments or weathered metamorphic overburden. Those dug wells were shallow, in which depths vary from $5 \mathrm{~m}$ to $10 \mathrm{~m}$ below the ground level. Some of them are down to depths of $30 \mathrm{~m}$. Most of the dug wells are covered from surface runoff by cement brick walls. Groundwater use for drinking purposes is considered an important factor for the etiology of CKDu. Therefore, the determination of the combination of geology, hydrogeology, and groundwater chemistry is important.

Dambethalawa GND in the Ampara district was selected as the reference sampling site for the study as low CKDu patients have reported under the same environmental and agricultural conditions. It is located in the Eastern Province. The total population of the Dambethalawa GND is around 2,700 , and the ratio between the female and male population is $1: 1$. The main occupation of the people in this area is paddy cultivation and also home gardening. Dambethalawa GND is located in the dry zone of the country, and the annual rainfall of the sampling area is about $1,500 \mathrm{~mm}$ to $2,000 \mathrm{~mm}$, mainly from October to December as in the CKDu prevalence area selected for the study, and the mean temperature of this area is around $30^{\circ} \mathrm{C}\left(28^{\circ} \mathrm{C}-32^{\circ} \mathrm{C}\right)$. Water samples from Dambethalawa GND were collected from drinking water wells that are shallow in depth. Most of the dug wells used for drinking water in this area are also protected by cement brick walls. The sampling locations in the Dambethalawa GND are shown in Figure 1(b).

2.2. Sample Analysis. A total of 30 drinking water samples were collected from each sampling site; CKDu hotspot (Girandurukotte GND) and the reference (Dambethalawa GND) were analyzed to achieve the aim of this study. For sampling, wells that had been in use for five or more years by households were selected. It was noted that some of these wells were used by more than one family. All the wells selected for this study are currently used by villagers for their drinking and household purposes. This study was conducted using the random sampling method across the study areas located in the home gardens of the residents. All the sampling locations were recorded in the field using the global positioning system (GPS). Sampling procedures were done within February 2020 (dry season) for both sampling sites. All the analyses were done in triplicates.

Electrical conductivity (EC), $\mathrm{pH}$, water temperature, and dissolved oxygen (DO) were measured using portable multiparameter field meters as on-site measurements according to the standard procedures. Fluoride concentrations of collected samples were measured at the site using a calibrated fluoride meter (Eutech Instrument, $\mathrm{pH} 510$ ). TISAB (III) buffer was used with the drinking water sample in a 1:1 ratio when taking the readings to stabilize the $\mathrm{pH}$.

For major ion analyses, two aliquots of $100 \mathrm{~mL}$ were collected into precleaned, uncontaminated Teflon bottles. One set was acidified with ultrapure nitric acid (69\% purity, Sigma-Aldrich, India) for trace element analysis, and the other set was not acidified. All drinking water samples were then preserved at $4^{\circ} \mathrm{C}$ until analysis. All the chemical analyses were carried out in CKDu Research and Information Centre, Sri Lanka.

For major trace element analysis, an amount of $15 \mathrm{~mL}$, which were preacidified, was filtered through a $0.45 \mu \mathrm{m}$ pore size disposable nylon syringe filter into falcon tubes. The concentrations of trace elements including cadmium $(\mathrm{Cd})$, chromium $(\mathrm{Cr})$, lead $(\mathrm{Pb})$, arsenic (As), copper $(\mathrm{Cu})$, zinc $(\mathrm{Zn})$, iron $(\mathrm{Fe})$, manganese $(\mathrm{Mn})$, aluminium $(\mathrm{Al})$, sodium $(\mathrm{Na})$, potassium $(\mathrm{K})$, calcium $(\mathrm{Ca})$, and magnesium $(\mathrm{Mg})$ were analyzed using inductively coupled plasma mass spectrometry (ICP-MS-7800-Agilent, Germany). Instrumental calibration was done using multielement ICP-MS standards (AccuStandard, USA; $0.1-10.0 \mu \mathrm{g} / \mathrm{L}$ and $100.00-2,000.00 \mu \mathrm{g} / \mathrm{L})$ to determine the small amounts of the heavy metals and major cations. Five standard solution 
series of $0.1 \mu \mathrm{g} / \mathrm{L}, 0.5 \mu \mathrm{g} / \mathrm{L}, 1.0 \mu \mathrm{g} / \mathrm{L}, 5.0 \mu \mathrm{g} / \mathrm{L}$, and $10.0 \mu \mathrm{g} / \mathrm{L}$ were used to construct the calibration curve for the heavy metal analysis of drinking water samples. Another five standard solution series of $100.00 \mu \mathrm{g} / \mathrm{L}, \quad 500.00 \mu \mathrm{g} / \mathrm{L}$, $1,000.00 \mu \mathrm{g} / \mathrm{L}, 1,500.00 \mu \mathrm{g} / \mathrm{L}$, and $2,000.00 \mu \mathrm{g} / \mathrm{L}$ were used to form the calibration curve for the major cations including $\mathrm{Na}, \mathrm{K}, \mathrm{Ca}$, and $\mathrm{Mg}$. The instrumental minimum detection limits (MDLs) for the measured metals and metalloids using ICP-MS in $\mu \mathrm{g} / \mathrm{L}$ were as follows: $\mathrm{Cd}$ (0.0005), $\mathrm{Cr}$ (0.0005), $\mathrm{Pb}$ (0.0005), As (0.001), $\mathrm{Cu}$ (0.0005), $\mathrm{Zn}$ (0.001), $\mathrm{Fe}$ (0.002), $\mathrm{Mn}$ (0.0005), $\mathrm{Al}(0.001), \mathrm{Na}(0.01), \mathrm{K}$ (0.05), $\mathrm{Ca}(0.005)$, and $\mathrm{Mg}(0.001)$. A correlation coefficient (R2) in the range of 0.99860-0.99999 was used to confirm the calibration curve. Blanks were always less than MDLs. The accuracy of the analytical procedure was checked by analyzing the standard reference materials. The accuracy of the analyses was verified with standard reference materials (ERM-CA615 - groundwater (trace elements), ERM ${ }^{\circledR}$ certified reference material (Sigma Aldrich, Germany)). Major anions including nitrate $\left(\mathrm{NO}_{3}^{-}\right)$, phosphate $\left(\mathrm{PO}_{4}^{2-}\right)$, and sulfate $\left(\mathrm{SO}_{4}^{2-}\right)$ concentrations of the drinking water samples were measured using ion chromatography (Metrohm Eco IC, Switzerland) instrument according to the USEPA standard procedures (Method 9056A). A mixture of sodium bicarbonate (Sigma-Aldrich, India, CASRN 14455-8) and sodium carbonate (Sigma-Aldrich, India, CASRN-497-19-7) was used as the elution solution, and sulfuric acid (CASRN-7664-93-9, Sigma-Aldrich, India) was used as the regeneration solution for IC. ACS reagent grade $1,000 \mathrm{mg} / \mathrm{L}$ stock solutions of nitrate, phosphate, and sulfate were used for the standards for anions prepared for a range of concentrations $(0.1 \mathrm{mg} / \mathrm{L}-10 \mathrm{mg} / \mathrm{L})$. Prepared standards and the nonacidified water samples were filtered through $0.22 \mu \mathrm{m}$ pore size disposable nylon syringe filters. Samples were introduced into the ion chromatography under the flow rate of $0.7 \mathrm{~mL} / \mathrm{min}$, and the anions of interest were separated and measured using a conductivity detector. Total hardness values were determined based on the $\mathrm{Ca}$ and $\mathrm{Mg}$ concentrations. It was calculated using the following equation where the concentrations of $\mathrm{Ca}$ and $\mathrm{Mg}$ are expressed in $\mathrm{mg} / \mathrm{L}$.

$$
\text { Total water hardness }=\left[2.5\left(\mathrm{Ca}^{2+}\right)+4.1\left(\mathrm{Mg}^{2+}\right)\right] .
$$

The factors 2.5 and 4.1 are the ratios of the formula weight of calcium carbonate (100) to the weights of $\mathrm{Ca}$ (40) and $\mathrm{Mg}(24.3)[79,80]$. Categorization of the total water hardness levels is shown in Table 1.

\subsection{Indexing Approach}

2.3.1. Water Quality Index (WQI). The water quality index (WQI) was calculated to determine the suitability of the collected water samples for drinking purposes. It reduces the water parameters to a single number, and it assists to determine the overall water quality at a certain location $[81,82]$. In this study, WQI was calculated for both CKDu prevalent area and reference area using the 12 measured parameters at each site, as in the following steps. The
TABLE 1: Water hardness scale.

\begin{tabular}{lc}
\hline Total water hardness $(\mathrm{mg} / \mathrm{L})$ & Status \\
\hline$<60$ & Soft water \\
$60-120$ & Moderately hard water \\
$120-180$ & Hard water \\
$>180$ & Very hard water \\
\hline
\end{tabular}

relative weights $(W i)$ of the selected chemical parameters were calculated using the following equation as the first step:

$$
W i=w i \div \sum_{i(1)=1}^{n} w i
$$

where $w i$ is the weight of each parameter, and $n$ is the number of hydrochemical parameters. The value of the wi for each parameter is varied from 1 to 5 according to the impact of the contaminant on human health [81]. Then, the quality rating scale $(Q i)$ of each parameter was estimated using the following equation:

$$
Q i=[(C i-C i p) \div(S i-C i p)] \times 100,
$$

where $C i$ is the concentration of each parameter in $\mathrm{mg} / \mathrm{L}, \mathrm{Si}$ is the standard permissible value for each parameter in $\mathrm{mg} / \mathrm{L}$, and Cip is the ideal value of the $i$ parameter in pure water (it considers $C j p=0$ for all, except the $\mathrm{pH}$ value where $C i p=7$ ). Finally, WQI was calculated using the obtained values for $W i$ and $Q i$ using the following equation:

$$
\mathrm{WQI}=\sum_{i=1}^{n} W i \times Q i .
$$

Then, the collected drinking water samples in both $\mathrm{CKDu}$ prevalent site and the reference site were categorized into different water types based on the calculated WQI values as in Table 2.

2.3.2. Chronic Daily Intake (CDI). Primarily, the human body absorbs hazardous compounds via drinking water, and therefore, the health effects of nephrotoxic heavy metals entered into the human body through drinking water were considered in both CKDu prevalent and reference sites. The chronic daily intake (CDI) risks due to ingesting a trace element were computed for the adult population according to the guidelines presented by US-EPA [ $81,84,85]$. The equation used is as follows:

$$
\mathrm{CDI}=\frac{C_{w} \times \mathrm{IRW} \times \mathrm{EF} \times \mathrm{ED}}{\mathrm{BW} \times \mathrm{AT}},
$$

where $\mathrm{CDI}$ is the chronic daily intake that is referred to as the exposure dose $(\mu \mathrm{g} / \mathrm{kg} /$ day $), C_{w}$ indicates the concentration of the contaminant in water, IRW signifies the water ingestion rate, EF represents the exposure frequency, ED denotes the exposure duration, BW signifies the body weight, and AT is the average exposure time [81, 86-88]. The key parameters used to assess the chronic daily intake (CDI) risks of nephrotoxic elements are shown in Table 3. 
TABLE 2: Status of water quality based on WQI [83].

\begin{tabular}{cccc}
\hline & WQI & Status & Grade \\
\hline 1 & $0-25$ & Excellent & $\mathrm{A}$ \\
2 & $26-50$ & Good & $\mathrm{B}$ \\
3 & $51-75$ & Poor & $\mathrm{C}$ \\
4 & $76-100$ & Very poor & $\mathrm{D}$ \\
5 & 100 and above & Unsuitable for drinking & $\mathrm{E}$ \\
\hline
\end{tabular}

TABLE 3: The key parameters for computing the CDI of nephrotoxic elements through drinking water.

\begin{tabular}{lcc}
\hline Parameter & Units & For an adult \\
\hline Ingestion rate (IRW) & L/day & 2.94 \\
Exposure frequency (EF) & Day/year & 365 \\
Exposure duration (ED) & Year & 70 \\
Body weight (BW) & $\mathrm{kg}$ & 70 \\
Average time (AT) & Days & 25550 \\
Concentration of element $(\mathrm{Cw})$ & $\mathrm{mg} / \mathrm{L}$ & Present study \\
\hline
\end{tabular}

2.3.3. Hazard Quotient (HQ). The hazard quotient (HQ) of a single element was computed using the following equation:

$$
\mathrm{HQ}=\frac{\mathrm{CDI}}{\mathrm{RfD}}
$$

where RfD denotes the reference dose of a selected trace metals $(\mathrm{mg} / \mathrm{kg} /$ day). The RfD values for analyzed nephrotoxic metals including $\mathrm{Cd}, \mathrm{Cr}, \mathrm{Pb}, \mathrm{As}, \mathrm{Cu}, \mathrm{Mn}, \mathrm{Zn}$, and $\mathrm{Al}$ were $0.001,0.003,0.0035,0.001,0.04,0.014,0.30$, and 0.001 , respectively $[75,80,89,90]$.

2.3.4. Hazard Index (HI). Hazard index is the summation of the hazard quotient values. The equation for the $\mathrm{HI}$ is as follows:

$$
\mathrm{HI}=\sum \mathrm{HQ} .
$$

If $\mathrm{HI}$ is greater than one $(\mathrm{HI}>1)$, it hints that the health risk of ingesting the particular nephrotoxic trace element is above the acceptable limit, whereas $\mathrm{HI}<1$ indicates that they are within the acceptance limit $[74,91]$. Therefore, the classification of the basis of HI values is (i) negligible (risk level 1: $\mathrm{HI}<0.1$ ), (ii) low risk (risk level 2 : $\mathrm{HI} \geq 0.1<1$ ), medium risk (risk level 3: $\mathrm{HI} \geq 1<4$ ), and high risk (risk level 4: $\mathrm{HI} \geq 4)[74,81,92]$.

2.3.5. Heavy Metal Evaluation Index (HEI). Heavy metal evaluation index (HEI) is a health risk assessment method that gives an overall quality of waters with respect to their heavy metal content [74, 93-95]. Therefore, HEI was calculated using the following equation:

$$
\mathrm{HEI}=\sum_{i=1}^{n} \frac{H_{c}}{H_{\mathrm{MAC}}}
$$

where $H_{c}$ signifies the monitored value and $H_{\mathrm{MAC}}$ denotes the maximum admissible concentration (MAC) of the $i$-th parameter.
2.3.6. Heavy Metal Pollution Index (HPI). The heavy metal pollution index (HPI) provides information about the overall water quality regarding the heavy metal contents. It is also a risk assessment method to determine the effects of individual heavy metals on the overall water quality and the drinking water suitability $[74,96]$. In this study, HPI value was calculated considering the concentrations of $\mathrm{Cd}, \mathrm{Cr}, \mathrm{Pb}$, $\mathrm{As}, \mathrm{Cu}, \mathrm{Mn}, \mathrm{Zn}$, and $\mathrm{Al}$ using the following equation $[74,93,97]$ :

$$
\mathrm{HPI}=\frac{\mathrm{HMC} / \mathrm{AL}}{n},
$$

where HMC represents the selected trace metal concentration in the water sample, AL signifies the allowable limit, and $n$ denotes the number of analyzed trace elements. Drinking water standards recommended by WHO [50] were used for the calculations.

2.4. Statistical Analysis and Geographical Data Analysis. Statistical analysis was performed with the SPSS software package at a significance level of 0.05 . Descriptive statistics were performed on the data sets, and paired $t$-test was carried out to assess the differences or similarities of the chemical parameters obtained for each sampling location. Comparisons were made for the drinking water quality of $\mathrm{CKDu}$ prevalent site and the reference site and the recommended by WHO [50] in stipulating drinking water quality standards. The spatial distribution of the obtained data was interpolated using the ArcMap 10.2.2 software package. Inverse distance weighted (IDW) and Moran's index (MI) tools in ArcMap 10.2.2 software were used to determine the impact of water quality in the CKDu prevalent site and reflect the spatial groundwater quality change pattern. The spatial autocorrelation aimed to determine the spatial distribution difference of the drinking water contaminants in Girandurukotte and Dambethalawa GNDs. In addition, variations of the contaminant concentration at each sampling point were analyzed using the maps generated using ArcMap software.

\section{Results and Discussion}

3.1. Major Physicochemical Characteristics of Drinking Water Samples. A total of 20 physicochemical parameters of collected drinking water samples in both CKDu prevalent and reference areas are summarized in Table 4 along with the drinking water quality standards recommended by WHO. The selected parameters determined were $\mathrm{pH}$, temperature, $\mathrm{DO}, \mathrm{EC}, \mathrm{Ca}, \mathrm{Mg}, \mathrm{Na}, \mathrm{K}, \mathrm{Cd}, \mathrm{Cr}, \mathrm{Pb}, \mathrm{As}, \mathrm{Cu}, \mathrm{Fe}, \mathrm{Mn}, \mathrm{Zn}, \mathrm{Al}$, $\mathrm{F}^{-}, \mathrm{PO}_{4}^{2-}, \mathrm{SO}_{4}^{2-}$, and $\mathrm{NO}_{3}^{-}$. Based on the results, the selected minerals and other physicochemical characteristics obtained from two geographical locations were varied. Therefore, it emphasizes that the geographical location influenced the mineral compositions and the physicochemical characteristics of the groundwater. The $\mathrm{pH}$ values of all the water samples were neutral to alkaline, and the highest (9.66) and the lowest (6.32) $\mathrm{pH}$ values were reported in non-CKDu prevalent GND. The mean temperature values of $\mathrm{CKDu}$ 
TABle 4: Physicochemical data of collected drinking water samples from both CKDu prevalent and reference GNDs.

\begin{tabular}{|c|c|c|c|c|c|c|c|}
\hline \multirow[t]{2}{*}{ Parameter and unit } & \multicolumn{3}{|c|}{$\begin{array}{c}\text { Girandurukotte GND (CKDu prevalent } \\
\text { area) }\end{array}$} & \multicolumn{3}{|c|}{ Dambethalawa GND (non-CKDu area) } & \multirow[t]{2}{*}{ Drinking water standard [50] } \\
\hline & Minimum & Maximum & Mean \pm SD & Minimum & Maximum & Mean \pm SD & \\
\hline $\mathrm{pH}$ & 6.63 & 8.74 & $7.03 \pm 0.52$ & 6.32 & 9.66 & $6.93 \pm 0.29$ & $6.5-8.5$ \\
\hline Temperature $\left({ }^{\circ} \mathrm{C}\right)$ & 27.85 & 31.20 & $28.65 \pm 3.21$ & 26.52 & 30.25 & $27.53 \pm 2.53$ & - \\
\hline $\mathrm{DO}(\mathrm{mg} / \mathrm{L})$ & 4.26 & 7.52 & $6.80 \pm 1.26$ & 5.41 & 15.62 & $9.52 \pm 4.56$ & $6.5-8.0$ \\
\hline $\mathrm{EC}(\mu \mathrm{S} / \mathrm{cm})$ & 111.63 & 1111.67 & $396.89 \pm 242.77$ & 10.20 & 647.00 & $210.76 \pm 148.82$ & 400 \\
\hline $\mathrm{Ca}(\mathrm{mg} / \mathrm{L})$ & 0.06 & 1.94 & $1.05 \pm 0.90$ & 0.35 & 1.25 & $0.58 \pm 0.20$ & 75 \\
\hline $\mathrm{Mg}(\mathrm{mg} / \mathrm{L})$ & 44.56 & 12.36 & $20.29 \pm 5.60$ & 1.26 & 4.56 & $2.035 \pm 0.04$ & 100 \\
\hline $\mathrm{Na}(\mathrm{mg} / \mathrm{L})$ & 3.88 & 30.25 & $8.08 \pm 5.26$ & 3.59 & 18.96 & $5.98 \pm 3.29$ & 200 \\
\hline $\mathrm{K}(\mathrm{mg} / \mathrm{L})$ & 0.20 & 0.45 & $0.29 \pm 0.25$ & 0.63 & 1.20 & $0.73 \pm 0.01$ & 200 \\
\hline $\mathrm{Cd}(\mu \mathrm{g} / \mathrm{L})$ & 0.03 & 0.34 & $0.13 \pm 0.07$ & 0.01 & 0.02 & $0.02 \pm 0.002$ & 3 \\
\hline $\mathrm{Cr}(\mu \mathrm{g} / \mathrm{L})$ & 20.75 & 103.35 & $54.75 \pm 18.38$ & 22.85 & 89.65 & $39.94 \pm 10.25$ & 50 \\
\hline $\mathrm{Pb}(\mu \mathrm{g} / \mathrm{L})$ & 0.08 & 0.66 & $0.20 \pm 0.13$ & 0.02 & 0.05 & $0.04 \pm 0.00$ & 10 \\
\hline As $(\mu \mathrm{g} / \mathrm{L})$ & 9.77 & 187.27 & $30.18 \pm 14.20$ & 1.83 & 13.56 & $5.80 \pm 2.30$ & 10 \\
\hline $\mathrm{Cu}(\mu \mathrm{g} / \mathrm{L})$ & 0.42 & 7.54 & $1.06 \pm 0.27$ & 0.32 & 3.81 & $1.38 \pm 0.40$ & 2000 \\
\hline $\mathrm{Fe}(\mu \mathrm{g} / \mathrm{L})$ & 8.24 & 484.61 & $108.31 \pm 54.37$ & 45.62 & 79.62 & $58.00 \pm 6.50$ & 300 \\
\hline $\operatorname{Mn}(\mu \mathrm{g} / \mathrm{L})$ & 86.92 & 344.92 & $118.45 \pm 67.04$ & 23.95 & 102.36 & $51.59 \pm 18.02$ & 400 \\
\hline $\mathrm{Zn}(\mu \mathrm{g} / \mathrm{L})$ & 2.00 & 85.16 & $18.40 \pm 16.66$ & 0.02 & 1.20 & $1.03 \pm 0.01$ & 300 \\
\hline $\mathrm{Al}(\mu \mathrm{g} / \mathrm{L})$ & 42.36 & 93.98 & $54.27 \pm 22.50$ & 64.52 & 15.20 & $21.56 \pm 5.04$ & 100 \\
\hline $\mathrm{F}^{-}(\mathrm{mg} / \mathrm{L})$ & 0.24 & 5.74 & $1.63 \pm 1.40$ & 0.24 & 0.85 & $0.62 \pm 0.23$ & 1.0 \\
\hline $\mathrm{PO}_{4}^{2-}(\mathrm{mg} / \mathrm{L})$ & 0.99 & 0.126 & $0.96 \pm 0.24$ & 0.52 & 1.52 & $0.74 \pm 0.31$ & 0.03 \\
\hline $\mathrm{SO}_{4}^{2-}(\mathrm{mg} / \mathrm{L})$ & 13.53 & 114.57 & $60.28 \pm 31.84$ & 20.85 & 89.65 & $68.52 \pm 15.62$ & 70 \\
\hline $\mathrm{NO}_{3}^{-}(\mathrm{mg} / \mathrm{L})$ & 10.29 & 35.62 & $20.56 \pm 9.54$ & 9.52 & 12.35 & $14.52 \pm 6.35$ & 50 \\
\hline
\end{tabular}

$\mathrm{SD}=$ Standard deviation.

prevalent and reference GNDs were $28.65 \pm 3.21^{\circ} \mathrm{C}$ and $27.53 \pm 2.53^{\circ} \mathrm{C}$, respectively. The mean electrical conductivity (EC) values in $\mathrm{CKDu}$ prevalent GND was ranged from $111.63 \mu \mathrm{S} / \mathrm{cm}$ to $1,111.67 \mu \mathrm{S} / \mathrm{cm}$ with a mean value of $396.89 \mu \mathrm{S} / \mathrm{cm}$. Considering the overall results of this study, mean values of $\mathrm{pH}, \mathrm{EC}, \mathrm{Mg}, \mathrm{Ca}, \mathrm{Na}, \mathrm{Fe}, \mathrm{F}^{-}, \mathrm{PO}_{4}^{3-}$, and $\mathrm{NO}_{3}^{-}$ were higher in drinking water samples collected from CKDu prevalent GND compared to their non-CKDu counterparts. Furthermore, the studied physicochemical characteristics, major cation concentrations, and the analyzed anion concentrations except for fluoride in both sampling locations were below the standard limits recommended by the WHO guidelines (Table 4).

The mean concentrations of $\mathrm{Cd}, \mathrm{Cr}, \mathrm{Pb}, \mathrm{As}, \mathrm{Cu}, \mathrm{Mn}, \mathrm{Zn}$, and $\mathrm{Al}$ in drinking water samples collected from Girandurukotte GND were $0.13 \pm 0.07 \mu \mathrm{g} / \mathrm{L}, 54.75 \pm 18.38 \mu \mathrm{g} / \mathrm{L}$, $0.20 \pm 0.13 \mu \mathrm{g} / \mathrm{L}, 30.18 \pm 14.20 \mu \mathrm{g} / \mathrm{L}, 1.06 \pm 0.27 \mu \mathrm{g} / \mathrm{L}, 108.31 \pm$ $54.37 \mu \mathrm{g} / \mathrm{L}, 18.40 \pm 16.66 \mu \mathrm{g} / \mathrm{L}$, and $54.27 \pm 22.50 \mu \mathrm{g} / \mathrm{L}$, respectively, while the mean concentrations of $\mathrm{Cd}, \mathrm{Cr}, \mathrm{Pb}, \mathrm{As}, \mathrm{Cu}$, $\mathrm{Mn}, \mathrm{Zn}$, and $\mathrm{Al}$ in drinking water samples collected from Dambethalawa GND were $0.02 \pm 0.00 \mu \mathrm{g} / \mathrm{L}, 39.94 \pm 10.25 \mu \mathrm{g} / \mathrm{L}$, $0.04 \pm 0.00 \mu \mathrm{g} / \mathrm{L}, \quad 5.80 \pm 2.30 \mu \mathrm{g} / \mathrm{L}, \quad 1.38 \pm 0.40 \mu \mathrm{g} / \mathrm{L}, \quad 58.00 \pm$ $6.50 \mu \mathrm{g} / \mathrm{L}, \quad 51.29 \pm 18.02 \mu \mathrm{g} / \mathrm{L}, \quad 1.03 \pm 0.01 \mu \mathrm{g} / \mathrm{L}$, and $21.56 \pm$ $5.04 \mu \mathrm{g} / \mathrm{L}$, respectively (Table 4 ). According to the obtained results, all the analyzed mean trace metal concentrations of drinking water samples in both sampling areas were complied with standard guideline values recommended by WHO (2011) [50], except Cr $(54.75 \pm 18.38 \mu \mathrm{g} / \mathrm{L})$ and As $(30.18 \pm 14.20 \mu \mathrm{g} / \mathrm{L})$ in water samples collected from Girandurukotte GND. Furthermore, it shows that the nephrotoxic trace elements in drinking water samples, including $\mathrm{Cd}, \mathrm{Cr}, \mathrm{Pb}, \mathrm{As}, \mathrm{Mn}, \mathrm{Zn}$, and $\mathrm{Al}$ collected from
$\mathrm{CKDu}$ prevalent area, were statistically significantly higher $(p<0.05)$ from the water samples collected from Dambethalawa GND. This indicates that a considerable change could be identified between the mean nephrotoxic heavy metal concentrations in Girandurukotte and Dambethalawa GNDs. The results of this study are similar to the results obtained by Balasooriya et al. [12], where the analyzed trace element concentrations were higher in $\mathrm{CKDu}$ wells compared to the non-CKDu wells. Moreover, it has been concluded that one of the major risk factors in $\mathrm{CKDu}$ prevalent areas is the presence of nephrotoxic heavy metals $[77,98]$. Although the concentrations of the heavy metals were low in analyzed drinking water samples, the long-term exposure to these nephrotoxicants may be harmful to the people in CKDu endemic areas as bioaccumulation and dehydration. Cadmium, chromium, lead, and arsenic deserve more attention as they are known as nephrotoxic heavy metals that disrupt kidney function. Furthermore, they are introduced as possible causative factors for the onset of CKDu in Sri Lanka $[12,13]$. According to the results, the mean concentrations of $\mathrm{Cd}, \mathrm{Cr}, \mathrm{Pb}$, and $\mathrm{As}$ in the $\mathrm{CKDu}$ prevalent area were higher compared to the non-CKDu site. Among them, $\mathrm{Cr}(54.75 \pm 18.38 \mu \mathrm{g} / \mathrm{L})$ and $\mathrm{As}(30.18 \pm 14.20 \mu \mathrm{g} / \mathrm{L})$ concentrations exceeded the maximum permissible levels recommended by $\mathrm{WHO}$, while the other two nephrotoxic heavy metals complied with standard levels (Figure 2).

The spatial distribution patterns of the selected trace elements are shown in Figures 3(a)-3(d). According to the results of the interpolated data via GIS, the concentrations of the $\mathrm{As}, \mathrm{Pb}, \mathrm{Cr}$, and $\mathrm{Cd}$ were ranged from $9.78-187.25 \mu \mathrm{g} / \mathrm{L}$, $0.08-0.66 \mu \mathrm{g} / \mathrm{L}, \quad 20.76-103.30 \mu \mathrm{g} / \mathrm{L}, \quad$ and $\quad 0.03-0.34 \mu \mathrm{g} / \mathrm{L}$, 


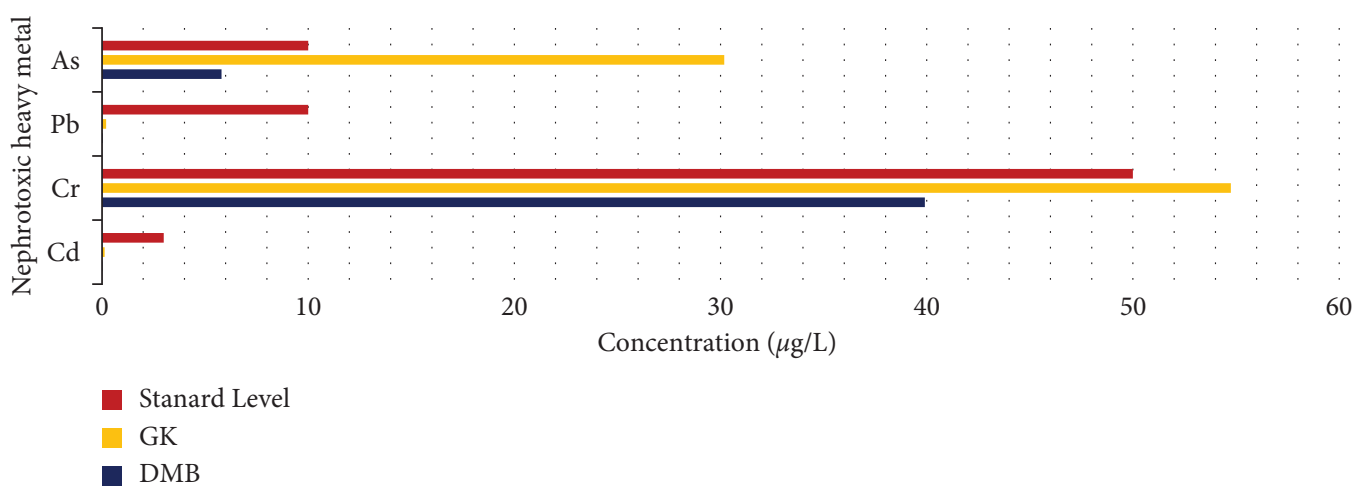

Figure 2: The graphical representation of $\mathrm{As}, \mathrm{Pb}, \mathrm{Cr}$, and $\mathrm{Cd}$ concentrations in collected drinking water samples from both $\mathrm{CKDu}$ prevalent Girandurukotte GND and reference Dambethalawa GND.

respectively, in the drinking water samples collected from Girandurukotte GND. All the nephrotoxic heavy metals are randomly distributed according to the obtained Moran's index values. Geochemical conditions, fertilizer runoff containing heavy metals, and other ionic agents may contribute to the pollution of drinking water sources in these areas [99]. However, nephrotoxic heavy metals play an important role in the onset of CKDu. Therefore, it is essential to regular monitoring and the proper construction of the drinking wells to seal off the surface contaminants.

Considering the nephrotoxicity of heavy metals, $\mathrm{Pb}$ causes the damages of mitochondria, free radical formation apoptosis, and intracellular depletion of Glutathione (GSH). According to the literature, $\mathrm{Pb}$ is the most notable and beststudied environmental nephrotoxic element. Acute $\mathrm{Pb}$ poisoning (blood lead levels $>80-100 \mu \mathrm{g} / \mathrm{dL}$ ) disrupts proximal tubular structure and function. Also, chronic $\mathrm{Pb}$ nephrotoxicity causes loss of kidney function and consequently elevated blood urea nitrogen and creatinine levels [100]. After exposure, $\mathrm{Pb}$ accumulates in proximal renal tubular lining cells as morphologically recognizable inclusion bodies, lead-protein complexes. Furthermore, chronic $\mathrm{Pb}$ toxicity leads to interstitial fibrosis, progressive nephron loss, azotemia, and renal failure. Gout and hypertension are two possible side effects of $\mathrm{Pb}$ nephropathy [101]. Considering the nephrotoxicity due to $\mathrm{Cr}$, the chromate is accumulated in the convoluted proximal tubule where necrosis occurs. According to the literature, the adverse long-term effect of low-dose $\mathrm{Cr}$ exposure on the kidneys is due to the low molecular weight (LMW) proteinuria. The long-term exposure to $\mathrm{Cr}$ leads to chromate-induced acute tubular necrosis (ATN) and LMW proteinuria, which may produce persistent renal injuries. Moreover, excessive urinary excretion of beta 2-microglobulin, a specific proximal tubule brush border protein, and retinol-binding protein has been reported among the workers in chromium plated welding houses [102]. Exposure to the As is a major public health problem due to its presence in nature in both inorganic or organic compounds. Osorio et al. [103] described acute tubular necrosis, renal cortical necrosis, diffuse interstitial fibrosis, and further progression to chronic kidney failures had been associated with As exposure. Some studies of higher As excretion have been linked with lower plasma lycopene levels, showing that kidney damage is mediated by an increase in oxidative stress [104]. According to the literature, a synergetic impact between As and Cd has been observed as people exposed to higher levels of both elements had a higher prevalence of albuminuria and LMW proteinuria than those who were simply exposed to As or Cd [105]. Cd causes the Fanconi syndrome, a widespread proximal tubular reabsorptive deficiency that is hypothesized to be caused by reducing ATP synthesis and $\mathrm{Na}-\mathrm{K}-\mathrm{ATPase}$ function at high enough cumulative doses. Increased excretion of beta 2 -microglobulin, retinol-binding protein, and alpha1-microglobulin, indicative of decreased proximal tubule function, are some of the major symptoms that herald the Cd nephrotoxicity [106]. With long-term exposure, Cd accumulates in the epithelial cells of the proximal tubule, causing widespread reabsorptive failure characterized by polyuria and low-molecular-weight proteinuria. The accumulation of $\mathrm{Cd}$ into the proximal tubule cells produces several relatively non-specific toxic effects that cause renal epithelial cells' death through necrotic or apoptotic pathways [107]. The previous human and animal studies based on nephrotoxic heavy metals including As, Cd, $\mathrm{Cr}$, and $\mathrm{Pb}$ show that these contaminants behave as significant risk factors for renal tubular alterations and acute or chronic renal failure, which may lead to chronic kidney diseases.

3.2. The Role of Fluoride and Water Hardness. The mean fluoride concentration level of the groundwater collected from Girandurukotte GND varied from $0.24 \mathrm{mg} / \mathrm{L}$ to $5.74 \mathrm{mg} / \mathrm{L}$ with a mean value of $1.63 \mathrm{mg} / \mathrm{L}$. Based on the results, the mean value of the fluoride concentration in Dambethalawa GND was $0.62 \mathrm{mg} / \mathrm{L}$, which varied from $0.24 \mathrm{mg} / \mathrm{L}$ to $0.85 \mathrm{mg} / \mathrm{L}$. The mean value of the fluoride in drinking water samples collected from Girandurukotte GND has exceeded the maximum permissible levels $(1.0 \mathrm{mg} / \mathrm{L})$ recommended by WHO, while the mean fluoride content of the drinking water samples collected from Dambethalawa has not exceeded the standard levels (Table 4). Mean fluoride values of both sampling locations were higher than the $0.6 \mathrm{mg} / \mathrm{L}$ that was considered as a threshold for optimal fluoride levels in drinking water recommended for the dry 


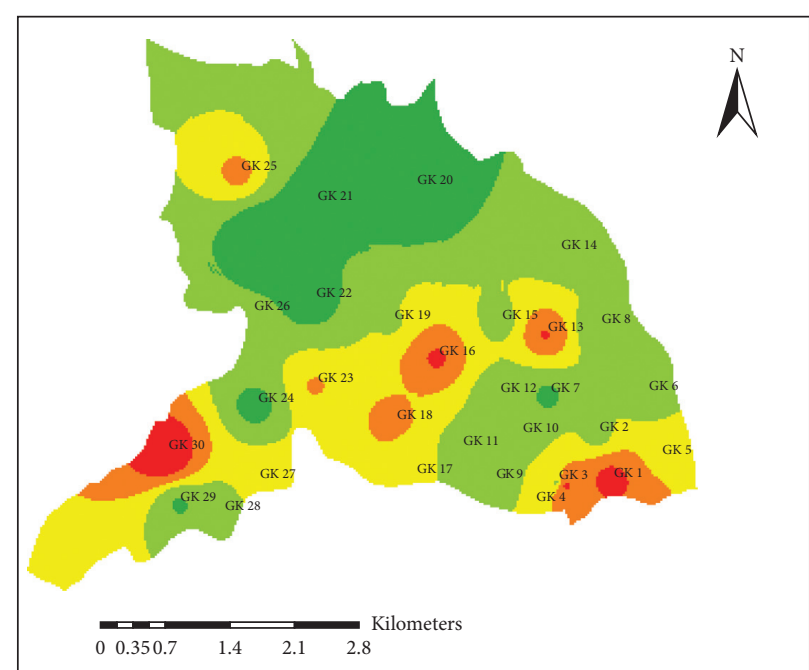

Sampling Points

Girandurukotte GND

Chromium

$\mu \mathrm{g} / \mathrm{L}$

ए $20.759-43.095$

$43.096-53.777$

$53.778-63.164$

$63.165-77.731$

$77.732-103.304$

(a)

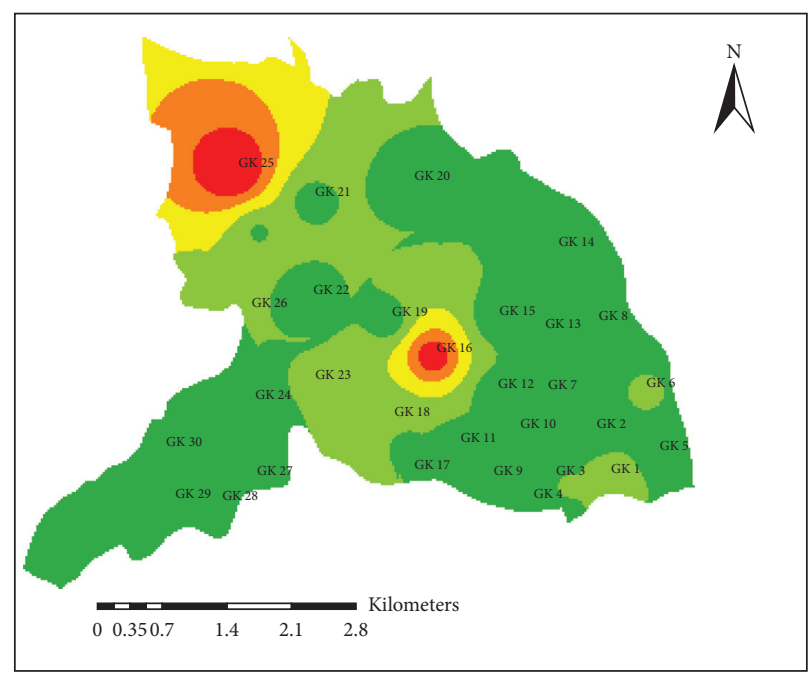

Sampling Points

Girandurukotte GND

Arsenic

$\mu \mathrm{g} / \mathrm{L}$

प $9.777-27.176$

$27.177-52.23$

$52.231-87.724$

$87.725-127.394$

$127.395-187.246$

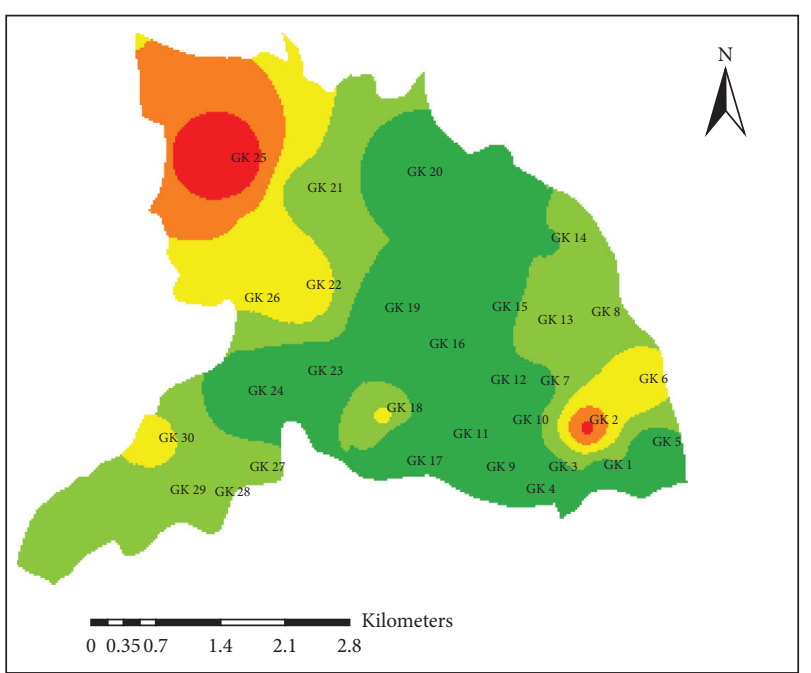

Sampling Points

Girandurukotte GND

Lead

$\mu \mathrm{g} / \mathrm{L}$

$0.083-0.173$

$0.174-0.245$

$0.246-0.335$

$0.336-0.459$

$0.460-0.657$

(b)

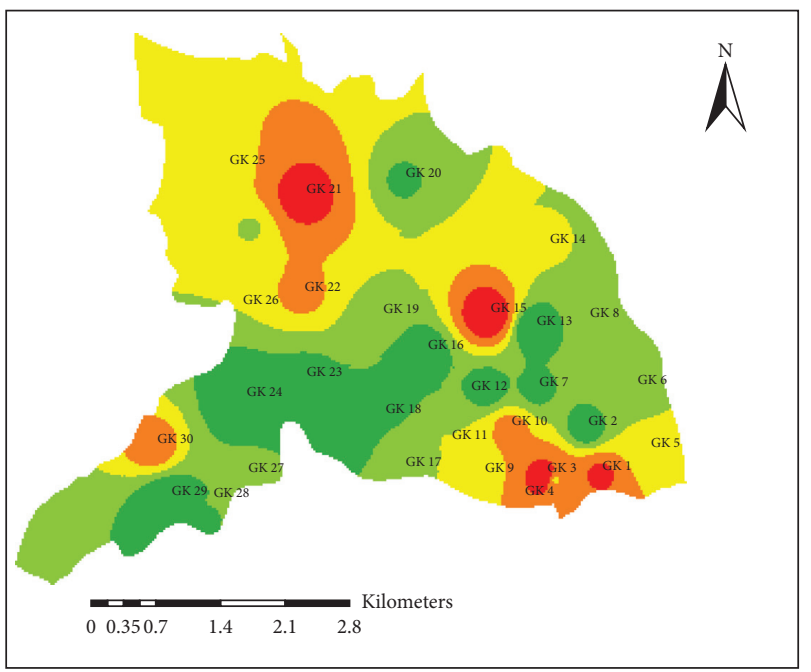

Sampling Points

Girandurukotte GND

Cadmium

$\mu \mathrm{g} / \mathrm{L}$

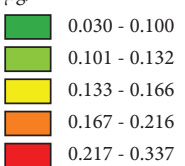

(c) (d)

FIgure 3: The geospatial distribution of (a) $\mathrm{Cr}$, (b) Pb, (c) As, and (d) Cd in the collected drinking water samples from Girandurukotte GND, Badulla district, Sri Lanka. 
zone of Sri Lanka [12, 108]. However, the frequency of occurrence above the threshold limit was $28 \%$ in non-CKDu water samples while $81 \%$ in CKDu prevalent. Similar observations have been reported in early studies that were carried out in CKDu prevalent areas in Sri Lanka.

Dissanayake and Chandrajith [53] described that a considerable amount of fluoride is added into the groundwater due to the regolith weathering of hard rock terrains in tropical climate conditions. Furthermore, fluorides are leaching into the groundwater from fluoridebearing minerals such as mica, hornblende, and apatite present in high-grade metamorphic rocks. The chemical similarities of hydroxyl and the fluoride ions facilitate the fluoride leaching process [12]. Excessive amounts and the long residence time of bicarbonates, exchange reactions of $\mathrm{Na}^{+}$and $\mathrm{Ca}^{2+}$ induce the mobilization and the enrichment of Fluorides in groundwater aquifers [109]. Moreover, the solute contents in drinking water, including fluorides, are increased in most temperate regions due to the strong evaporation rates $[12,110]$. Considering the link between environmental fluoride exposure and the onset of $\mathrm{CKDu}$ is an important role as the kidneys are among the main pathways of excreting fluoride from the body $[12,111]$. Most of the studies have proven that exposure to excessive levels of fluoride along with drinking water may affect kidney damages [12, 112, 113]. Moreover, some of the major health problems related to the fluorides in $\mathrm{CKDu}$ prevalent areas are dental and skeletal fluorosis [77]. Interestingly, the combination of the fluorides in drinking water along with water hardness can be affected to the onset of CKDu. Therefore, it is crucial to investigate the relationship between the fluoride and the water hardness towards the CKDu.

$\mathrm{Ca}^{2+}$ and $\mathrm{Mg}^{2+}$ are the most important cations that contribute to water hardness. The total water hardness levels of each sampling point in Girandurukotte GND and Dambethalawa GND are shown in Figures 4 and 5, respectively. According to the results, the mean water hardness value in Girandurukotte GND was $83.58 \pm 27.90 \mathrm{mg} / \mathrm{L}$, which indicates the "moderately hard water." The highest and the lowest water hardness values were $22.95 \mathrm{mg} / \mathrm{L}$ (soft water) and $174.2 \mathrm{mg} / \mathrm{L}$ (hard water), respectively (Figure 4). The highest and the lowest hardness values of the drinking water collected from Dambethalawa GND were $103.51 \mathrm{mg} / \mathrm{L}$ (moderately hard water) and $13.43 \mathrm{mg} / \mathrm{L}$ (soft water), respectively, with a mean value of $31.62 \pm 19.93 \mathrm{mg} / \mathrm{L}$ that indicates the "soft water" category (Figure 5). Based on the results obtained by the study, the water hardness of the drinking water collected from CKDu prevalent Girandurukotte GND was higher compared to the hardness values denotes by the drinking water collected from Dambethalawa GND. Correspondingly, the earlier study of Dissanayake et al. [114] has reported that the fluoride levels and the water hardness levels are higher in CKDu prevalence areas than in $\mathrm{CKDu}$ nonprevalence areas.

The increase of weathering under tropical conditions may be one factor for higher amounts of fluoride and water hardness $[12,59]$. Slow movement or stagnant groundwater conditions lead to the dissolution of aquifer minerals. This may be combined with low dilution from mixing with other waters as the groundwater pockets are deeper. Fluoridebearing minerals can dissolve in such a situation, and in time, water hardness and EC increase [12, 52]. Notably, fluoride interactions with water hardness show a controlling effect on the $\mathrm{CKDu}$, which is depending on their dosage and saturation factors $[4,5,48]$. Therefore, this emphasizes the close relationship between CKDu with the synergistic effect of high water hardness and high fluoride in drinking water. Furthermore, the chemical forms of fluoride and other trace elements in water are modified in the presence of hardness that may act as a secondary factor of the unknown etiology [54]. Figure 6 shows the spatial distribution patterns of fluoride (Figure 6(a)) and water hardness (Figure 6(b)) of the sampling locations in Girandurukotte GND, which is the $\mathrm{CKDu}$ endemic area. According to the inverse distance weighted (IDW) method, the fluoride concentrations in drinking water samples collected from Girandurukotte GND was varied from $0.244 \mathrm{mg} / \mathrm{L}-5.743 \mathrm{mg} / \mathrm{L}$, while the water hardness values were varied from $22.98 \mathrm{mg} / \mathrm{L}-174.01 \mathrm{mg} / \mathrm{L}$.

3.3. Water Quality Index (WQI). The suitability of the collected drinking water samples was analyzed using the weighted arithmetic water quality index method. The most commonly used water quality parameters, including $\mathrm{pH}, \mathrm{EC}$, $\mathrm{F}^{-}, \mathrm{SO}_{4}^{2-}, \mathrm{NO}_{3}^{-}, \mathrm{PO}_{4}^{3-}, \mathrm{Ca}^{2+}, \mathrm{Mg}^{2+}, \mathrm{Cd}, \mathrm{Cr}, \mathrm{Pb}$, and As, were selected to classify the drinking water samples based on their purity. The results of this method were computed following the technique and guidelines as outlined by Egbueri and Mgbenu [75]. The results of the WQI obtained for two sampling areas are summarized in Table 5.

The WQI values were varied from 42.53 to 96.23 , with a mean value of $71.53 \pm 13.34$ for Girandurukotte GND. The status of the drinking water quality of the CKDu prevalent samples was "poor," while the drinking water samples in non-CKDu samples signify "good" as the status. The WQI values of non-CKDu samples were varied from 15.62 to 75.23 with a mean value of $42.70 \pm 13.54$. It was observed that $90 \%$ of the samples in the CKDu prevalent area were classified as "poor water" and "very poor water" for drinking purposes, while $10 \%$ of the samples indicate the "good" water quality with a "B" grade. Furthermore, only the $26.67 \%$ samples collected from the non-CKDu area showed the "poor" and "very poor" water quality. The rest $(73.33 \%)$ of the samples were of "good" and "excellent" water quality for drinking usage. However, such variation in water quality might be due to the geological characteristics of the aquifers, nature, and depth of water sources. WQI leads to a straightforward interpretation of water quality by assembling different parameters into a single number [80]. In conclusion, it can be pointed up according to the WQI values that most of the drinking water samples collected from CKDu prevalent areas are not suitable for drinking and other household purposes compared to the ware samples collected from the non-CKDu area, which indicates the "good water" status. Therefore, it is essential to pay attention and enhance the water pollution control measures when using the water from the contaminated level high areas. 


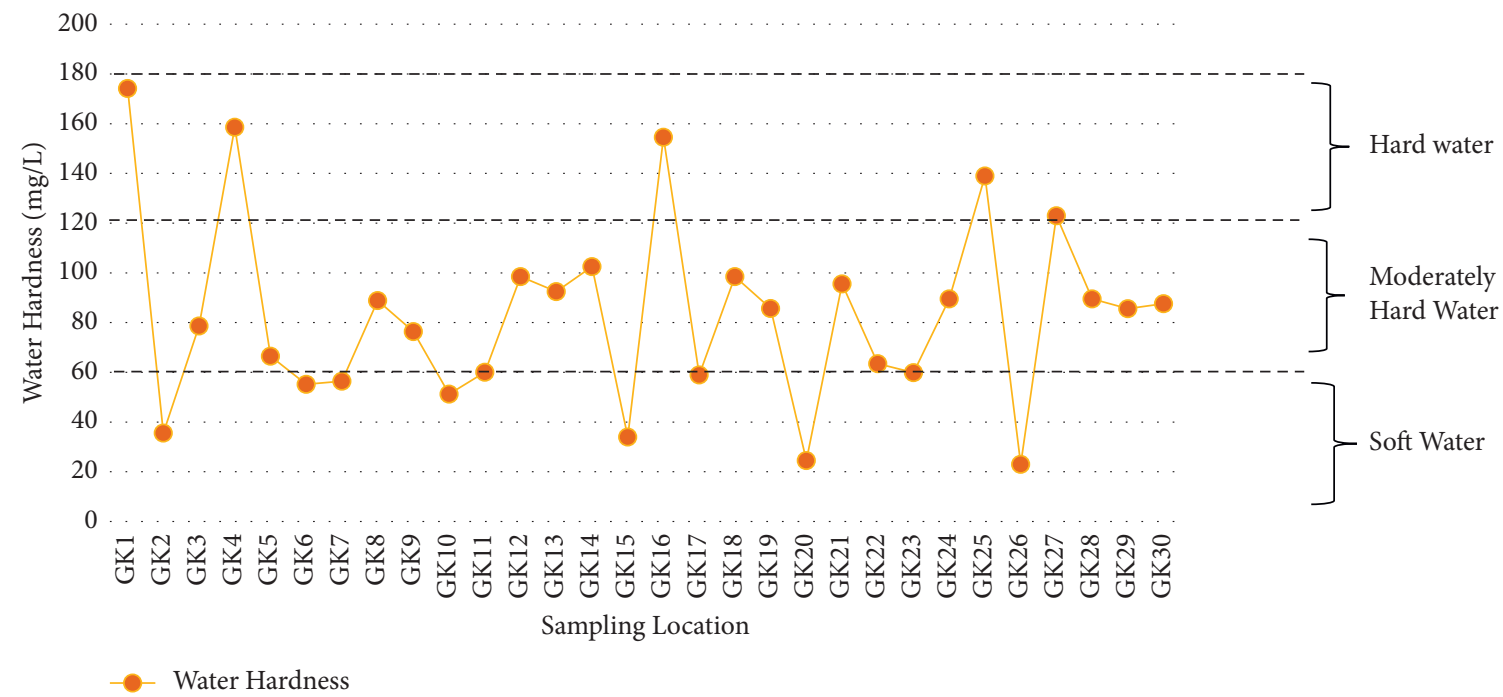

Figure 4: Total water hardness in drinking water samples collected from Girandurukotte GND, Badulla district, Sri Lanka. All data were presented as the mean of three replicates $(\mathrm{mg} / \mathrm{L})$.

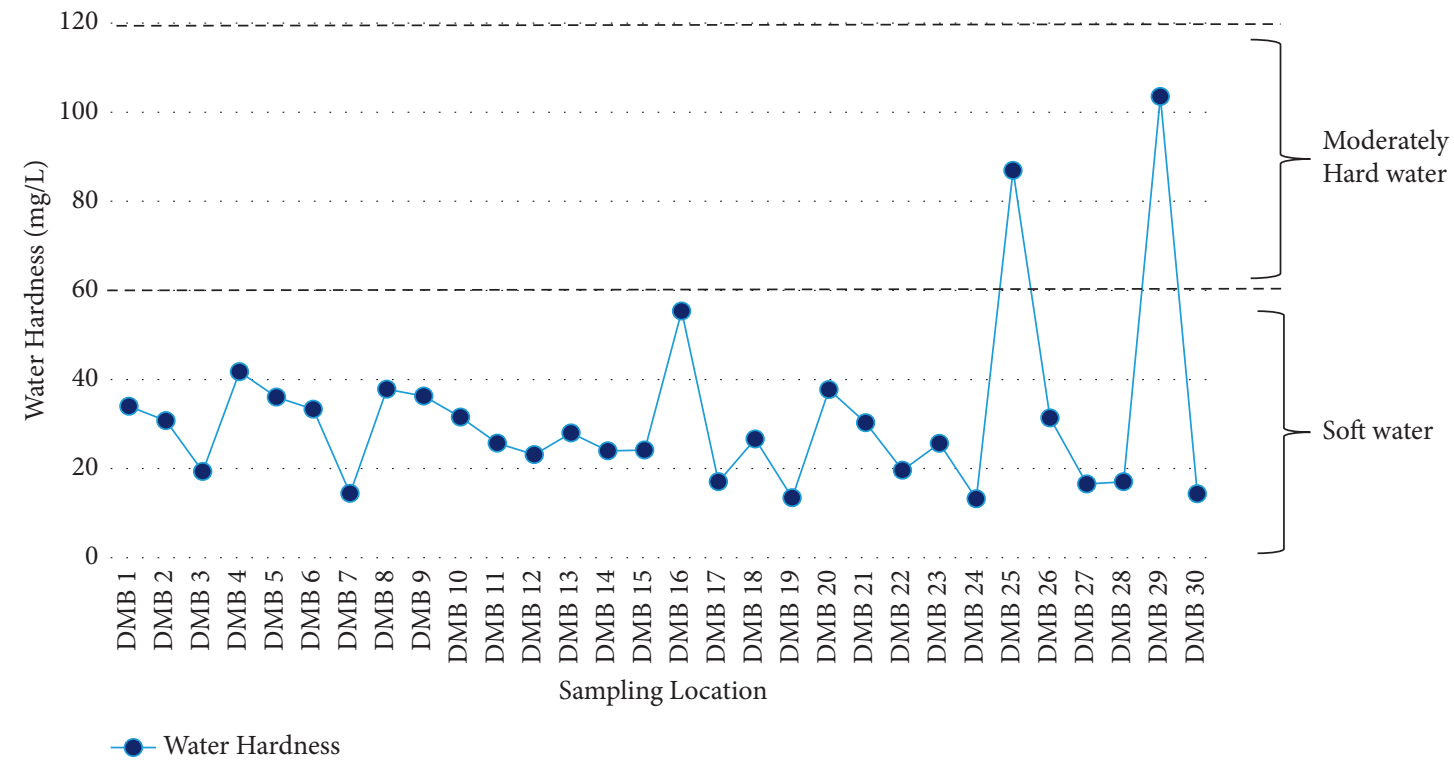

FIgure 5: Total water hardness in drinking water samples collected from Dambethalawa GND, Ampara district, Sri Lanka. All data were presented as the mean of three replicates $(\mathrm{mg} / \mathrm{L})$.

3.4. Health Risk Assessment Using Water Quality Indices. The statistical summary of the health risk assessment indices for the selected trace elements in drinking water collected from $\mathrm{CKDu}$ endemic and reference area are presented in Table 6 . The calculated CDI (oral) values obtained by the study were $5 \times 10^{-6} \mathrm{mg} / \mathrm{kg} /$ day, $2.31 \times 10^{-3} \mathrm{mg} / \mathrm{kg} /$ day, $8 \times 10^{-6} \mathrm{mg} / \mathrm{kg} /$ day, $1.26 \times 10^{-3} \mathrm{mg} / \mathrm{kg} /$ day, $4.20 \times 10^{-5} \mathrm{mg} /$ $\mathrm{kg} /$ day, $4.956 \times 10^{-3} \mathrm{mg} / \mathrm{kg} / \mathrm{day}, 7.73 \times 10^{-3} \mathrm{mg} / \mathrm{kg} /$ day, and $2.27 \times 10^{-3} \mathrm{mg} / \mathrm{kg} /$ day for $\mathrm{Cd}, \mathrm{Cr}, \mathrm{Pb}, \mathrm{As}, \mathrm{Cu}, \mathrm{Mn}, \mathrm{Zn}$, and $\mathrm{Al}$ in Girandurukotte GND. In contrast, the oral CDI values in the Dambethalawa GND were $1 \times 10^{-6}, 1.68 \times 10^{-3}, 2 \times 10^{-6}$, $2.44 \times 10^{-4}, \quad 5.80 \times 10^{-5}, \quad 2.17 \times 10^{-3}, \quad 4.30 \times 10^{-5}, \quad$ and $9.06 \times 10^{-4}$ for $\mathrm{Cd}, \mathrm{Cr}, \mathrm{Pb}, \mathrm{As}, \mathrm{Cu}, \mathrm{Mn}, \mathrm{Zn}$, and $\mathrm{Al}$, respectively. The potential health risk through ingestion of waters was measured based on the HQ and HI. In this study, the adult population was considered as the target group. The calculated $\mathrm{HQ}$ (oral) values for $\mathrm{Cd}, \mathrm{Cr}, \mathrm{Pb}, \mathrm{As}, \mathrm{Cu}, \mathrm{Mn}, \mathrm{Zn}$, and $\mathrm{Al}$ were $5.46 \times 10^{-3}, 7.70 \times 10^{-1}, 2.40 \times 10^{-3}, 1.26 \times 10^{0}$, $1.05 \times 10^{-3}, 3.54 \times 10^{-1}, 2.58 \times 10^{-2}$, and $2.27 \times 10^{-1}$ in Girandurukotte GND and $8.4 \times 10^{-4}, 5.59 \times 10^{-1}, 4.80 \times 10^{-4}$, $2.44 \times 10^{-1}, \quad 1.45 \times 10^{-3}, \quad 1.55 \times 10^{-1}, \quad 1.44 \times 10^{-4}$, and $9.06 \times 10^{-2}$ for the drinking water collected from Dambethalawa GND, respectively. Based on the results obtained for HQ (oral), it can be summarized that the contribution of the nephrotoxic trace elements to the human health risk was in the sequence of $\mathrm{As}>\mathrm{Cr}>\mathrm{Mn}>\mathrm{Al}>\mathrm{Zn}>\mathrm{Cd}>\mathrm{Pb}>\mathrm{Cu}$ in 


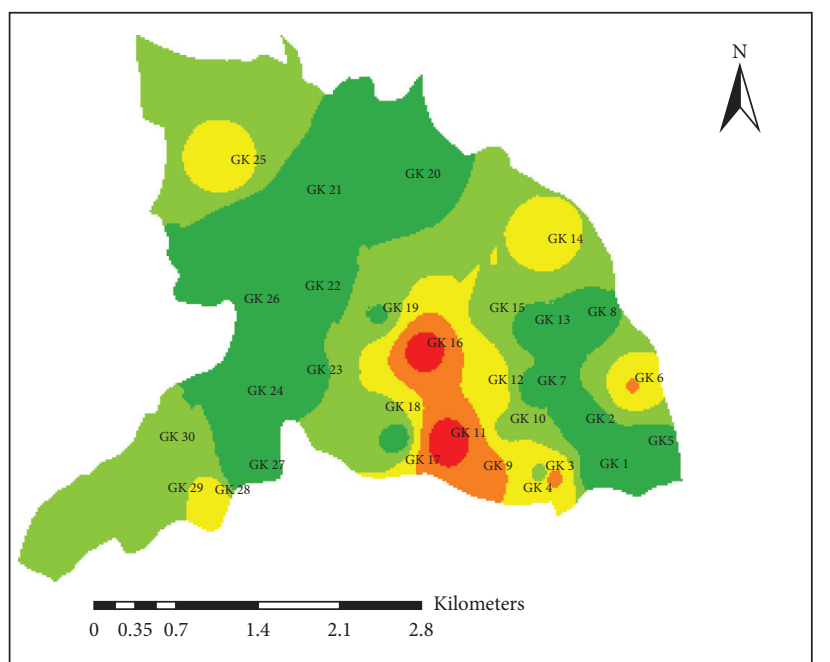

Sampling Points

Girandurukotte GND

Fluoride

$\mathrm{mg} / \mathrm{L}$

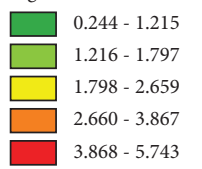

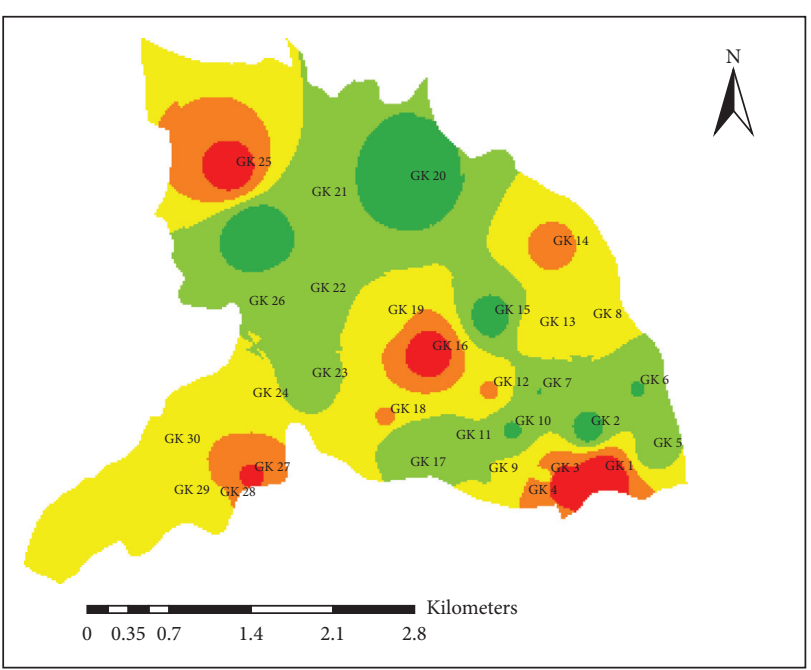

Sampling Points

Girandurukotte GND

water_hardness

$\mathrm{mg} / \mathrm{L}$

\begin{tabular}{|l|l}
\hline & $22.978-56.738$ \\
$\square$ & $56.739-76.876$ \\
$\square$ & $76.877-94.052$ \\
$\square$ & $94.053-117.151$ \\
$\square$ & $117.152-174.011$
\end{tabular}

(a)

(b)

Figure 6: The spatial distribution patterns of (a) fluoride and (b) water hardness in sampling locations of Girandurukotte GND, Badulla District, Sri Lanka.

TABLE 5: Water quality index (WQI) values and the relative description of drinking water samples collected from CKDu prevalent and non$\mathrm{CKDu}$ prevalent areas in Sri Lanka.

\begin{tabular}{|c|c|c|c|c|c|c|}
\hline \multirow{2}{*}{ Sample ID } & \multicolumn{3}{|c|}{ CKDu prevalent area (Girandurukotte GND) } & \multicolumn{3}{|c|}{ Non-CKDu prevalent area (Dambethalawa GND) } \\
\hline & WQI value & Description & Grade & WQI value & Description & Grade \\
\hline 1 & 68.65 & Poor & $\mathrm{C}$ & 38.62 & Good & $\mathrm{B}$ \\
\hline 2 & 78.65 & Very poor & $\mathrm{D}$ & 54.23 & Poor & $\mathrm{C}$ \\
\hline 3 & 84.52 & Very poor & $\mathrm{D}$ & 42.36 & Good & $\mathrm{B}$ \\
\hline 4 & 86.23 & Very poor & $\mathrm{D}$ & 21.56 & Excellent & $\mathrm{A}$ \\
\hline 5 & 42.53 & Good & $\mathrm{B}$ & 36.52 & Good & B \\
\hline 6 & 78.69 & Very poor & $\mathrm{D}$ & 45.23 & Good & $\mathrm{B}$ \\
\hline 7 & 87.96 & Very poor & $\mathrm{D}$ & 75.23 & Very poor & $\mathrm{D}$ \\
\hline 8 & 89.65 & Very poor & $\mathrm{D}$ & 32.65 & Good & B \\
\hline 9 & 72.65 & Poor & $\mathrm{C}$ & 26.53 & Good & B \\
\hline 10 & 68.89 & Poor & $\mathrm{C}$ & 42.36 & Good & B \\
\hline 11 & 68.92 & Poor & $\mathrm{C}$ & 35.62 & Good & B \\
\hline 12 & 56.98 & Poor & $\mathrm{C}$ & 48.63 & Good & B \\
\hline 13 & 78.62 & Very poor & $\mathrm{D}$ & 32.52 & Good & $\mathrm{B}$ \\
\hline 14 & 65.92 & Poor & $\mathrm{C}$ & 45.32 & Good & B \\
\hline 15 & 84.62 & Very poor & $\mathrm{D}$ & 52.36 & Poor & $\mathrm{C}$ \\
\hline 16 & 78.92 & Very poor & $\mathrm{D}$ & 56.32 & Poor & $\mathrm{C}$ \\
\hline 17 & 71.56 & Poor & $\mathrm{C}$ & 63.52 & Poor & $\mathrm{C}$ \\
\hline 18 & 70.23 & Poor & $\mathrm{C}$ & 46.35 & Good & B \\
\hline 19 & 81.23 & Very poor & $\mathrm{D}$ & 51.25 & Poor & $\mathrm{C}$ \\
\hline 20 & 69.35 & Poor & $\mathrm{C}$ & 43.23 & Good & B \\
\hline 21 & 59.62 & Poor & $\mathrm{C}$ & 65.32 & Poor & $\mathrm{C}$ \\
\hline 22 & 60.23 & Poor & $\mathrm{C}$ & 45.68 & Good & B \\
\hline 23 & 78.45 & Very poor & $\mathrm{D}$ & 15.62 & Excellent & $\mathrm{A}$ \\
\hline 24 & 45.62 & Good & $\mathrm{B}$ & 52.36 & Poor & $\mathrm{C}$ \\
\hline 25 & 76.32 & Very poor & $\mathrm{D}$ & 44.52 & Good & B \\
\hline 26 & 45.96 & Good & $\mathrm{B}$ & 32.52 & Good & $\mathrm{B}$ \\
\hline
\end{tabular}


TABLE 5: Continued.

\begin{tabular}{lccccc}
\hline \multirow{2}{*}{ Sample ID } & \multicolumn{2}{c}{ CKDu prevalent area (Girandurukotte GND) } & \multicolumn{2}{c}{ Non-CKDu prevalent area (Dambethalawa GND) } \\
& WQI value & Description & Grade & WQI value & Description \\
\hline 27 & 96.32 & Very poor & D & 25.47 & Good \\
28 & 78.52 & Very poor & D & 27.82 & B \\
29 & 60.52 & Poor & C & 32.56 & Good \\
30 & 59.48 & Poor & C & 48.52 & Good \\
Mean & $\mathbf{7 1 . 5 3}$ & & & $\mathbf{4 2 . 7 0}$ & B \\
Minimum & $\mathbf{4 2 . 5 3}$ & Poor & C & $\mathbf{1 5 . 6 2}$ & Good \\
Maximum & $\mathbf{9 6 . 3 2}$ & & & $\mathbf{7 5 . 2 3}$ & B \\
SD & $\mathbf{1 3 . 3 5}$ & & & 13.52 & \\
\hline
\end{tabular}

"Poor" indicates the status of the WQI in the CKDu prevalent area. "C" indicates the grade obtained for the WQI in the CKDu prevalent area. "Good" indicates the status of the WQI in the non-CKDu prevalent area. "B" indicates the grade obtained for the WQI in the non-CKDu prevalent area. These are based on Table 2.

TABLE 6: The calculated chronic daily intake (CDI) and hazard quotient (HQ) values of drinking water samples collected from CKDu prevalent and non-CKDu prevalent areas, Sri Lanka.

\begin{tabular}{lccccccccc}
\hline & Sampling site & $\mathrm{Cd}$ & $\mathrm{Cr}$ & $\mathrm{Pb}$ & $\mathrm{As}$ & $\mathrm{Cu}$ & $\mathrm{Mn}$ & $\mathrm{Zn}$ & $\mathrm{Al}$ \\
\hline \multirow{2}{*}{ CDI (oral; mg/kg/day) } & $\mathrm{GK}$ & $5 \times 10^{-6}$ & $2.31 \times 10^{-3}$ & $8 \times 10^{-6}$ & $1.26 \times 10^{-3}$ & $4.20 \times 10^{-5}$ & $4.96 \times 10^{-3}$ & $7.73 \times 10^{-3}$ & $2.27 \times 10^{-3}$ \\
& $\mathrm{DMB}$ & $1 \times 10^{-6}$ & $1.68 \times 10^{-3}$ & $2 \times 10^{-6}$ & $2.44 \times 10^{-4}$ & $5.80 \times 10^{-5}$ & $2.17 \times 10^{-3}$ & $4.30 \times 10^{-5}$ & $9.06 \times 10^{-4}$ \\
\multirow{2}{*}{ HQ (oral) } & $\mathrm{GK}$ & $5.46 \times 10^{-3}$ & $7.70 \times 10^{-1}$ & $2.40 \times 10^{-3}$ & $1.26 \times 10^{\circ}$ & $1.05 \times 10^{-3}$ & $3.54 \times 10^{-1}$ & $2.58 \times 10^{-2}$ & $2.27 \times 10^{-1}$ \\
& $\mathrm{DMB}$ & $8.4 \times 10^{-4}$ & $5.59 \times 10^{-1}$ & $4.80 \times 10^{-4}$ & $2.44 \times 10^{-1}$ & $1.45 \times 10^{-3}$ & $1.55 \times 10^{-1}$ & $1.44 \times 10^{-4}$ & $9.06 \times 10^{-2}$ \\
\hline
\end{tabular}

$\mathrm{GK}=$ Girandurukotte and $\mathrm{DMB}=$ Dambethalawa .

TABLE 7: The estimated hazard index (HI), hazard evaluation index (HEI), and hazard pollution index (HPI) values for the drinking water samples collected from CKDu endemic and reference areas, Sri Lanka.

\begin{tabular}{lccc}
\hline & Hazard index (HI) & Hazard evaluation index (HEI) & Hazard pollution index (HPI) \\
\hline CKDu endemic area (GK) & 2.65 & 5.04 & 0.63 \\
Reference area (DMB) & 0.95 & 1.73 & 0.22 \\
\hline
\end{tabular}

Girandurukotte $\mathrm{GND}$ and $\mathrm{Cr}>\mathrm{As}>\mathrm{Mn}>\mathrm{Al}>\mathrm{Cu}>\mathrm{Cd}>$ $\mathrm{Pb}>\mathrm{Zn}$ in Dambethalawa GND, respectively. The calculated HQ oral values for all the drinking water samples were below 1.0. It indicates that all trace elements were within an acceptable level of harmful health risk for both locations. Furthermore, the HQ values obtained for the CKDu endemic area were significantly higher compared to the HQ values obtained for the reference area $(p<0.05)$. However, the HI values, indicated in Table 7 , obtained for the adult population in CKDu endemic area exceeding the acceptable limit $(H I=1)$ indicate that there are potential health risks to the people in those areas compared to the reference area. Thus, it can be concluded that the drinking water in CKDu endemic areas possessed more harmful health effects compared to the people in the reference area. However, these results may be important for the decision-makers, and they will provide the general risk information in the study areas to make proper decisions. Furthermore, groundwater management is important in the CKDu endemic study area.

The calculated HEI and HPI values for the drinking water samples collected from CKDu endemic and reference areas are shown in Table 7. HEI was calculated to determine the overall quality of the drinking water collected from both $\mathrm{CKDu}$ endemic and reference areas in the context of nephrotoxic hazard elements, which is important to identify and quantify the contamination levels of water. The mean
HEI values in $\mathrm{CKDu}$ endemic and reference areas were 5.04 and 1.73 , respectively. Furthermore, the HPI values obtained for the CKDu endemic and reference areas were 0.63 and 0.22 . As $\mathrm{HPI}<20$ indicates the safe water quality, all the analyzed drinking water samples are safe for drinking purposes. However, the mean concentrations of heavy metals and other nephrotoxic elements in the drinking water obtained from $\mathrm{CKDu}$ prevalent areas were significantly higher compared to the reference areas where no or low CKDu patients. Furthermore, relatively higher levels of toxic contaminant concentrations obtained in the CKDu prevalent areas may be due to the agricultural activities of paddy fields as most of the agrochemicals including fertilizers and pesticides consist of excessive amounts of toxic elements [99]. Thus, considering the health risk in the CKDu endemic areas compared to the non-CKDu areas, it is recommended to carry out the regular monitoring of nephrotoxic elements and establishing proper long-term drinking water treatment technologies for the CKDu affected area to reduce the harmful effect of drinking water.

\section{Conclusion}

The primary source of drinking water is groundwater in the Girandurukotte GND, where the CKDu is widely spread. Among the sampled wells, both CKDu prevailing and non- 
$\mathrm{CKDu}$ drinking waters showed low concentrations of nephrotoxic trace elements, including $\mathrm{As}, \mathrm{Pb}, \mathrm{Cr}$, and $\mathrm{Cd}$ complied with maximum permissible levels recommended by the WHO. However, there were statistically significant differences in these nephrotoxic elements in drinking waters between the $\mathrm{CKDu}$ prevailing and non-CKDu sites. Therefore, it can be concluded that long-term exposure to nephrotoxic trace elements may affect the loss of kidney functions. According to the spatial distribution patterns of the nephrotoxic heavy metals assessed through the ArcMap 10.2.2 software, a strong correlation can be observed between the heavy metal clustering and agriculturally intensive regions (in the $\mathrm{CKDu}$ prevalence site-Girandurukotte GND). The highest values obtained by the spatial autocorrelation for $\mathrm{As}, \mathrm{Pb}, \mathrm{Cr}$, and Cd were $187.25 \mu \mathrm{g} / \mathrm{L}, 0.66 \mu \mathrm{g} /$ $\mathrm{L}, 103.30 \mu \mathrm{g} / \mathrm{L}$, and $0.34 \mu \mathrm{g} / \mathrm{L}$, respectively, in the drinking water samples collected from $\mathrm{CKDu}$ prevalent site. Geochemical conditions, fertilizer runoff bearing heavy metals, and other ionic agents may play a key role in the contaminations of drinking water sources in these areas. In addition, drinking water in the CKDu prevailing site showed higher concentrations of fluoride and water hardness compared to the reference site, which exceeded the maximum permissible levels recommended by WHO. It may be due to the geographical differences, long-term residence times in hard rock aquifers. Therefore, this study suggests that the water hardness in combination with fluoride also may be responsible for the deterioration of kidney functions. Thus, the health effects of fluoride together with water hardness and the molecular mechanism related to fluoride and water hardness need further investigations. Furthermore, this paper evaluates the possible health risk assessment using various water quality indices in CKDu prevalent and non-CKDu areas. Based on the WQI, about $90 \%$ of the total samples in Girandurukotte were classed as "poor water" and "very poor water" for drinking purposes. In comparison, $73.33 \%$ of the samples in Dambethalawa were classed as "good" and "excellent" water quality. The computed HI values revealed potential health risks to the people in the $\mathrm{CKDu}$ prevalent area compared to the reference area as the $\mathrm{HI}$ values obtained for the adult population in CKDu endemic area exceeded the acceptable limit. Overall, the results of the study show the interrelation between the onset of $\mathrm{CKDu}$ and the quality of drinking water. Therefore, further studies on water quality monitoring can be recommended to investigate the sources and pathways of the contaminations of nephrotoxic elements, fluorides, and other ions that contributed to the prevalence of $\mathrm{CKDu}$.

\section{Data Availability}

The data used to support the findings of this study are included within the article.

\section{Conflicts of Interest}

The authors declare that they have no known conflicts of interest.

\section{Acknowledgments}

The authors would like to acknowledge Mr. Ruwan Perera, Ms. Nalika Roshani, Mr. Amitha Suriyaarachchi, and Ms. Erandi Udayasiri for supporting the sample collection and Mr. Amila Kannangara for providing technical assistance in instrumentation. This research was supported by the research project (PS/DSP/CKDU/06/3.5) titled "Establish a $\mathrm{CKDu}$ Information and Research Center at University of Kelaniya, Sri Lanka."

\section{References}

[1] K. B. Jayasekara, D. M. Dissanayake, R. Sivakanesan, A. Ranasinghe, R. H. Karunarathna, and G. W. G. Priyantha Kumara, "Epidemiology of chronic kidney disease, with special emphasis on chronic kidney disease of uncertain etiology, in the north central region of Sri Lanka," Journal of Epidemiology, vol. 25, no. 4, pp. 275-280, 2015.

[2] E. C. Craciun and I. Rosculescu, "On Danubian endemic familial nephropathy (Balkan nephropathy)," The American Journal of Medicine, vol. 49, no. 6, pp. 774-779, 1970.

[3] M. F. Elledge, J. H. Redmon, K. E. Levine, R. J. Wickremasinghe, K. P. Wanigasariya, and R. PeirisJohn, Chronic Kidney Disease of Unknown Etiology in Sri Lanka: Quest for Understanding and Global Implications, RTI Press Publication, Research Triangle Park, NC, USA, 2014.

[4] R. Chandrajith, S. Nanayakkara, K. Itai et al., "Chronic kidney diseases of uncertain etiology (CKDue) in Sri Lanka: geographic distribution and environmental implications," Environmental Geochemistry and Health, vol. 33, no. 3, pp. 267-278, 2011.

[5] R. Chandrajith, C. B. Dissanayake, T. Ariyarathna, H. M. J. M. K. Herath, and J. P. Padmasiri, "Dose-dependent $\mathrm{Na}$ and $\mathrm{Ca}$ in fluoride-rich drinking water -Another major cause of chronic renal failure in tropical arid regions," The Science of the Total Environment, vol. 409, no. 4, pp. 671-675, 2011.

[6] T. N. C. Athuraliya, T. Abeysekera, P. H. Amerasinghe et al., A Baseline Study on Early Renal Disease in a Selected Community of the North Central Province of Sri Lanka, Research Report, Faculty of Medicine and Science, University of Peradeniya, Galaha, Sri Lanka, 2003.

[7] T. Athuraliya, D. Abeysekera, P. Amerasinghe, P. Kumarasiri, and V. Dissanayake, "Prevalence of chronic kidney disease in two tertiary care hospitals: high proportion of cases with uncertain aetiology," Ceylon Medical Journal, vol. 54, no. 1, pp. 23-25, 2009.

[8] S. K. Gunatilake, S. S. Samaratunga, and R. T. Rubasinghe, "Chronic kidney disease (CKD) in Sri Lanka-current research evidence justification: a review," Sabaragamuwa University Journal, vol. 13, no. 2, pp. 31-58, 2015.

[9] A. V. Ranasinghe, G. W. G. P. Kumara, R. H. Karunarathna et al., "The incidence, prevalence and trends of chronic kidney disease and chronic kidney disease of uncertain aetiology $(\mathrm{CKDu})$ in the North central province of Sri Lanka: an analysis of 30,566 patients," BMC Nephrology, vol. 20, no. 1, p. 338, 2019.

[10] J. H. Redmon, M. F. Elledge, D. S. Womack et al., "Additional perspectives on chronic kidney disease of unknown aetiology (CKDu) in Sri Lanka-lessons learned from the WHO CKDu population prevalence study," BMC Nephrology, vol. 15, no. 1, p. 125, 2014. 
[11] S. J. Wimalawansa, "The role of ions, heavy metals, fluoride, and agrochemicals: critical evaluation of potential aetiological factors of chronic kidney disease of multifactorial origin $(\mathrm{CKDmfo} / \mathrm{CKDu})$ and recommendations for its eradication," Environmental Geochemistry and Health, vol. 38, no. 3, pp. 639-678, 2015.

[12] S. Balasooriya, H. Munasinghe, A. T. Herath et al., "Possible links between groundwater geochemistry and chronic kidney disease of unknown etiology (CKDu): an investigation from the Ginnoruwa region in Sri Lanka," Exposure and Health, vol. 12, no. 4, pp. 823-834, 2019.

[13] N. Jayatilake, S. Mendis, P. Maheepala, and F. R. Mehta, "Chronic kidney disease of uncertain aetiology: prevalence and causative factors in a developing country," $\mathrm{BMC} \mathrm{Ne}$ phrology, vol. 14, no. 1, p. 180, 2013.

[14] S. Nanayakkara, S. Senevirathna, T. Abeysekera et al., "An integrative study of the genetic, social and environmental determinants of chronic kidney disease characterized by tubulointerstitial damages in the North Central Region of Sri Lanka," Journal of Occupational Health, vol. 56, no. 1, pp. 28-38, 2014.

[15] S. Nanayakkara, S. T. M. L. D. Senevirathna, K. H. Harada et al., "Systematic evaluation of exposure to trace elements and minerals in patients with chronic kidney disease of uncertain etiology $(\mathrm{CKDu})$ in Sri Lanka," Journal of Trace Elements in Medicine \& Biology, vol. 54, pp. 206-213, 2019.

[16] S. J. Wimalawansa, "Escalating chronic kidney diseases of multi-factorial origin in Sri Lanka: causes, solutions, and recommendations," Environmental Health and Preventive Medicine, vol. 19, no. 6, pp. 375-394, 2014.

[17] A. P. Grollman and B. Jelaković, "Role of environmental toxins in endemic (Balkan) nephropathy," Journal of the American Society of Nephrology, vol. 18, no. 11, pp. 28172823, 2007.

[18] A. M. E. I. Nahas and A. K. Belle, "Chronic kidney disease: the global challenge," The Lancet, vol. 365, no. 9645, pp. 331-340, 2005.

[19] K. Wanigasuriya, "Aetiological factors of chronic kidney disease in the North central province of Sri Lanka: a review of evidence to-date," Journal of the College of Community Physicians of Sri Lanka, vol. 17, no. 1, 2012.

[20] S. Wickramarathna, S. Balasooriya, S. Diyabalanage, and R. Chandrajith, "Tracing environmental aetiological factors of chronic kidney diseases in the dry zone of Sri Lanka-a hydrogeochemical and isotope approach," Journal of Trace Elements in Medicine \& Biology, vol. 44, pp. 298-306, 2017.

[21] N. T. C. Athuraliya, T. D. J. Abeysekera, P. H. Amerasinghe et al., "Uncertain etiologies of proteinuric-chronic kidney disease in rural Sri Lanka," Kidney International, vol. 80, no. 11, pp. 1212-1221, 2011.

[22] M. M. Rajapurkar, G. T. John, A. L. Kirpalani et al., "What do we know about chronic kidney disease in India: first report of the Indian CKD registry," BMC Nephrology, vol. 13, no. 10, 2012.

[23] D. V. Reddy and A. Gunasekar, "Chronic kidney disease in two coastal districts of Andhra Pradesh, India: role of drinking water," Environmental Geochemistry and Health, vol. 35, no. 4, pp. 439-454, 2013.

[24] O. E. Minshawy, "End-stage renal disease in the El-Minia Governorate, upper Egypt: an epidemiological study," Saudi Journal of Kidney Disease and Transplantation, vol. 22, no. 5, pp. 1048-1054, 2011.

[25] D. R. VanDervort, D. L. López, C. M. Orantes, and D. S. Rodríguez, "Spatial distribution of unspecified chronic kidney disease in El Salvador by crop area cultivated and ambient temperature," MEDICC Review, vol. 16, no. 2, pp. 31-38, 2014.

[26] D. G. A. Paranagama, M. A. Bhuiyan, and N. Jayasuriya, "Factors associated with chronic kidney disease of unknown aetiology $(\mathrm{CKDu})$ in North Central Province of Sri Lanka: a comparative analysis of drinking water samples," Applied Water Science, vol. 8, no. 6, p. 151, 2018.

[27] WHO, World Health Organization, Investigation and Evaluation of Chronic Kidney Disease of Unknown Etiology of Uncertain Aetiology in Sri Lanka, Final Report, Ministry of Health (MoH), Singapore, 2012.

[28] T. Cooray, Y. Wei, H. Zhong, L. Zheng, S. K. Weragoda, and R. Weerasooriya, "Assessment of groundwater quality in CKDu affected areas of Sri Lanka: implications for drinking water treatment," International Journal of Environmental Research and Public Health, vol. 16, no. 10, p. 1698, 2019.

[29] M. Almaguer, R. Herrera, and C. M. Orantes, "Chronic kidney disease of unknown etiology in agricultural communities," MEDICC Review, vol. 16, no. 2, pp. 9-15, 2014.

[30] S. Rajapakse, M. C. Shivanthan, and M. Selvarajah, "Chronic kidney disease of unknown etiology in Sri Lanka," International Journal of Occupational and Environmental Health, vol. 22, no. 3, pp. 259-264, 2016.

[31] K. Kafle, S. Balasubramanya, and T. Horbulyk, "Prevalence of chronic kidney disease in Sri Lanka: a profile of affected districts reliant on groundwater," The Science of the Total Environment, vol. 694, Article ID 133767, 2019.

[32] P. Vlahos, S. L. Schensul, N. Nanayakkara et al., "Kidney progression project (KiPP): protocol for a longitudinal cohort study of progression in chronic kidney disease of unknown etiology in Sri Lanka," Global Public Health, vol. 14, no. 2, pp. 214-226, 2019.

[33] J. Jayasekara, D. Dissanayake, S. Adhikari, and P. Bandara, "Geographical distribution of chronic kidney disease of unknown origin in North Central Region of Sri Lanka," Ceylon Medical Journal, vol. 58, no. 1, pp. 6-10, 2013.

[34] W. C. S. Wanasinghe, M. H. J. P. Gunarathna, H. M. P. I. K. Herath, and G. Y. Jayasinghe, "Drinking water quality on chronic kidney disease of unknown aetiology (CKDu) in Ulagalla cascade, Sri Lanka," Sabaragamuwa University Journal, vol. 16, no. 1, pp. 17-27, 2018.

[35] T. P. Burt and K. D. N. Weerasinghe, "Rainfall distributions in Sri Lanka in Time and space: an analysis based on daily rainfall data," Climate, vol. 2014, no. 2, pp. 242-263, 2014.

[36] C. Jayasumana, S. Gunatilake, and p. Senanayake, "Glyphosate, hard water and nephrotoxic metals: are they the culprits behind the epidemic of chronic kidney disease of unknown etiology in Sri Lanka?" International Journal of Environmental Research and Public Health, vol. 11, no. 2, pp. 2125-2147, 2014.

[37] A. Hittarage, "Chronic renal disease in North Central province, Balkan nephropathy- an equivalent in Sri Lanka," Annual Medical Journal, vol. 3, pp. 3-5, 2004.

[38] M. R. D. L. Kulathunga, M. A. Ayanka Wijayawardena, R. Naidu, and A. W. Wijeratne, "Chronic kidney disease of unknown aetiology in Sri Lanka and the exposure to environmental chemicals: a review of literature," Environmental Geochemistry and Health, vol. 41, no. 5, pp. 2329-2338, 2019.

[39] C. Jayasumana, S. Fonseka, A. Fernando et al., "Phosphate fertilizer is a main source of arsenic in areas affected with chronic kidney disease of unknown etiology in Sri Lanka," SpringerPlus, vol. 24, no. 4, p. 90, 2015. 
[40] S. Wijetunge, N. V. I. Ratnatunga, T. D. J. Abeysekera, A. W. M. Wazil, and M. Selvarajah, "Endemic chronic kidney disease of unknown etiology in Sri Lanka: correlation of pathology with clinical stages," Indian Journal of Nephrology, vol. 25, no. 5, pp. 274-280, 2015.

[41] Y. Tanchev and D. Dorossiev, "The first clinical description of Balkan endemic nephropathy (1956) and its validity 35 years later," IARC Science Publications, vol. 115, pp. 21-28, 1991.

[42] M. W. C. Dharma-wardana, S. L. Amarasiri, N. Dharmawardene, and C. R. Panabokke, "Chronic kidney disease of unknown aetiology and ground-water ionicity: study based on Sri Lanka," Environmental Geochemistry and Health, vol. 37, no. 2, pp. 221-231, 2015.

[43] J. M. R. S. Bandara, D. M. A. N. Senevirathna, D. M. R. S. B. Dasanayake et al., "Chronic renal failure among farm families in cascade irrigation systems in Sri Lanka associated with elevated dietary cadmium levels in rice and freshwater fish (Tilapia)," Environmental Geochemistry and Health, vol. 30, no. 5, pp. 465-478, 2008.

[44] O. A. Ileperuma, H. A. Dharmagunawardhane, and K. P. R. P. Herath, "Dissolution of aluminium from substandard utensils under high fluoride stress: a possible risk factor for chronic renal failure in the North-Central Province," Journal of the National Science Foundation of Sri Lanka, vol. 37, no. 3, pp. 219-222, 2009.

[45] F. B. Nerbass, R. Pecoits-Filho, W. F. Clark, J. M. Sontrop, C. W. McIntyre, and L. Moist, "Occupational heat stress and kidney health: from farms to factories," Kidney International Reports, vol. 2017, no. 2, pp. 998-1008, 2017.

[46] L. Senevirathna, T. Abeysekera, S. Nanayakkara et al., "Risk factors associated with disease progression and mortality in chronic kidney disease of uncertain etiology: a cohort study in Medawachchiya, Sri Lanka," Environmental Health and Preventive Medicine, vol. 17, no. 3, pp. 191-198, 2012.

[47] C. B. Dissanayake, "Water quality in the dry zone of Sri Lanka-some interesting health aspects," Journal of the $\mathrm{Na}$ tional Science Foundation of Sri Lanka, vol. 33, no. 3, pp. 161-168, 2010.

[48] C. B. Dissanayake and R. Chandrajith, "Fluoride and hardness in groundwater of tropical regions - review of recent evidence indicating tissue calcification and calcium phosphate nanoparticle formation in kidney tubules," Ceylon Journal of Science, vol. 48, no. 3, pp. 197-207, 2019.

[49] K. Gobalarajah, P. Subramaniam, U. A. Jayawardena, G. Rasiah, S. Rajendra, and J. Prabagar, "Impact of water quality on chronic kidney disease of unknown etiology $(\mathrm{CKDu})$ in Thunukkai division in Mullaitivu district, Sri Lanka," BMC Nephrology, vol. 21, no. 1, p. 507, 2020.

[50] W. HO. Hardness, Drinking Water, Document for Development of WHO Guidelines for Drinking Water Quality, The World Health Organization, Geneva, Switzerland, 2011.

[51] W. Chen, N. Krage, L. Wu, G. Pan, M. Khosrivafard, and A. C. Chang, "Arsenic, cadmium, and lead in California cropland soils: role of phosphate and micronutrient fertilizers," Journal of Environmental Quality, vol. 37, no. 2, pp. 689-695, 2008.

[52] A. Gunatilaka, "Panabokke C.R. (2007) groundwater conditions in Sri Lanka: a geomorphic perspective. National science foundation of Sri Lanka," Journal of the National Science Foundation of Sri Lanka, vol. 36, no. 1, pp. 113-114, 2008.

[53] C. B. Dissanayake and R. Chandrajith, "The hydrogeological and geochemical characteristics of groundwater of Sri Lanka," in Groundwater of South Asia. Springer
Hydrogeology, A. Mukherjee, Ed., Springer, Singapore, pp. 405-428, 2018.

[54] H. M. S. Wasana, D. Aluthpatabendi, W. M. T. D. Kularatne, P. Wijekoon, R. Weerasooriya, and J. Bandara, "Drinking water quality and chronic kidney disease of unknown etiology (CKDu): synergic effects of fluoride, cadmium and hardness of water," Environmental Geochemistry and Health, vol. 38, no. 1, pp. 157-168, 2016.

[55] P. Ball and J. E. Hallsworth, "Water structure and chaotropicity: their uses, abuses and biological implications," Physical Chemistry Chemical Physics, vol. 17, no. 13, pp. 8297-8305, 2015

[56] J. E. Bunnell, C. A. Tatu, H. E. Lerch, W. H. Orem, N. Pavlovic, and A. Kolker, "Evaluating nephrotoxicity of high-molecular-weight organic compounds in drinking water from lignite aquifers," Journal of Toxicology and Environmental Health, Part A, vol. 70, no. 24, pp. 2089-2091, 2007.

[57] S. Charlesworth, E. De Miguel, and A. Ordóñez, "A review of the distribution of particulate trace elements in urban terrestrial environments and its application to considerations of risk," Environmental Geochemistry and Health, vol. 33, no. 2, pp. 103-123, 2011.

[58] I. Sabolić, "Common mechanisms in nephropathy induced by toxic metals," Nephron Physiology, vol. 104, no. 3, pp. 107-114, 2006.

[59] R. Chandrajith, C. B. Dissanayake, and H. J. Tobschall, “The abundances of rarer trace elements in paddy (rice) soils of Sri Lanka," Chemosphere, vol. 58, no. 10, pp. 1415-1420, 2005.

[60] H. Wijesinghe, F. S. Idroos, and P. M. Manage, "Heavy metal contamination status in seven fish species from reservoirs of Polonnaruwa district, Sri Lanka," Sri Lanka Journal of Aquatic Sciences, vol. 23, no. 1, pp. 95-104, 2018.

[61] P. A. S. A. Rathnasri and P. M. Manage, "Evaluation of groundwater quality in five grama divisions of Maharagama urban area using groundwater quality index (WQI)," International Journal of Multidisciplinary Studies, vol. 2, no. 2, pp. 57-62, 2015.

[62] E. Singovszka, M. Balintova, S. Demcak, and P. Pavlikova, "Metal pollution indices of bottom sediment and surface water affected by acid mine drainage," Metals, vol. 7, no. 8, p. 284, 2017.

[63] M. Sojka, J. Jaskula, and M. Siepak, "Heavy metals in bottom sediments of reservoirs in the lowland area of western Poland: concentrations, distribution, sources and ecological risk," Water, vol. 11, no. 1, p. 56, 2019.

[64] W. P. R. T. Perera, M. D. N. R. Dayananda, D. M. U. C. Dissanayake et al., "Risk assessment of trace element contamination in drinking water and agricultural soil: a study in selected chronic kidney disease of unknown etiology (CKDu) endemic areas in Sri Lanka," Journal of Chemistry, vol. 2021, Article ID 6627254, 10 pages, 2021.

[65] K. P. Wanigasuriya, R. J. Peiris-John, and R. Wickremasinghe, "Chronic kidney disease of unknown aetiology in Sri Lanka: is cadmium a likely cause?" BMC Nephrology, vol. 12, no. 1, p. 32, 2011.

[66] J. N. Sommar, M. K. Svensson, B. M. Björ et al., "End-stage renal disease and low level exposure to lead, cadmium and mercury; a population-based, prospective nested case-referent study in Sweden," Environmental Health, vol. 23, no. 12, p. 9, 2013.

[67] E. Sabath and M. L. Robles-Osorio, "Renal health and the environment: heavy metal nephrotoxicity," Nefrologia: 
publicacion oficial de la Sociedad Espanola Nefrologia, vol. 32, no. 3, pp. 279-286, 2012.

[68] C. Cobbett and P. Goldsbrough, "Phytochelatins and metallothioneins: roles in heavy metal detoxification and homeostasis," Annual Review of Plant Biology, vol. 53, no. 1, pp. 159-182, 2002.

[69] F. A. Oguzie and G. A. Okhagbuzo, "Concentrations of heavy metals in effluent discharges downstream of Ikpoba river in Benin City, Nigeria," African Journal of Biotechnology, vol. 93, no. 3, pp. 319-325, 2010.

[70] E. F. Madden and B. A. Fowler, "Mechanisms of nephrotoxicity from metal combinations: a review," Drug and Chemical Toxicology, vol. 23, no. 1, pp. 1-12, 2000.

[71] A. Ishaque, L. Johnson, T. Gerald, D. Boucaud, J. Okoh, and P. Tchounwou, "Assessment of individual and combined toxicities of four non-essential metals ( $\mathrm{As}, \mathrm{Cd}, \mathrm{Hg}$ and $\mathrm{Pb}$ ) in the microtox assay," International Journal of Environmental Research and Public Health, vol. 3, no. 1, pp. 118120, 2006.

[72] R. L. Gutie'rrez, H. Rubio-Arias, R. Quintana, J. A. Ortega, and M. Gutierrez, "Heavy metals in water of the San Pedro River in Chihuahua, Mexico and its potential health risk," International Journal of Environmental Research and Public Health, vol. 5, no. 2, pp. 91-98, 2008.

[73] L. Zhu, M. Yang, X. Chen, and J. Liu, "Health risk assessment and risk control: drinking groundwater in yinchuan plain, China," Exposure and Health, vol. 11, no. 1, pp. 59-72, 2017.

[74] J. C. Eubueri and C. N. Mgbenu, "Chemo-metric analysis for pollution source identification and human health risk assessment of water resources in Ojoto Province, southeast Nigeria," Applied Water Science, vol. 10, p. 98, 2020.

[75] J. C. Egbueri, "Heavy metals pollution source identification and probabilistic health risk assessment of shallow groundwater in Onitsha, Nigeria," Analytical Letters, vol. 53, no. 10, pp. 1620-1638, 2020.

[76] M. M. Rahman, M. A. Islam, M. Bodrud-Doza et al., "Spatiotemporal assessment of groundwater quality and human health risk: a case study in Gopalganj, Bangladesh," Exposure and Health, vol. 10, no. 3, pp. 167-188, 2017.

[77] V. M. Jayasooriya, V. M. M. Perera, and S. Muthukumaran, "Rainwater as an alternative drinking water source for the Chronic Kidney Disease of Uncertain etiology ( $\mathrm{CKDu})$ prone areas: a case study for Girandurukotte, Sri Lanka," Journal of Water, Sanitation and Hygiene for Development, vol. 10, no. 3, pp. 39-548, 2020.

[78] H. M. Abeywickrama, K. M. S. Wimalasiri, Y. Koyama et al., "Assessment of nutritional status and dietary pattern of a rural adult population in dry zone, Sri Lanka," International Journal of Environmental Research and Public Health, vol. 17, no. 1, p. 150, 2019.

[79] S. Amarasiri, Caring of Water, Greater Kandy Water Supply Project, Sri Lanka, Second ed. edition, 2015.

[80] H. M. Zakir, S. Sharmin, and M. S. Rahman, "Assessment of health risk of heavy metals and water quality indices for irrigation and drinking suitability of waters: a case study of Jamalpur Sadar area, Bangladesh," Environmental Advances, vol. 2, 2020.

[81] Y. Zhang, J. Wu, and B. Xu, "Human health risk assessment of groundwater nitrogen pollution in Jinghui canal irrigation area of the loess region, northwest China," Environmental Earth Sciences, vol. 77, no. 7, p. 273, 2018.

[82] R. E. Rabeiy, "Assessment and modeling of groundwater quality using WQI and GIS in Upper Egypt area,"
Environmental Science and Pollution Research, vol. 25, no. 31, pp. 30808-30817, 2018.

[83] P. R. Chatterjee and M. Raziuddin, "Studies on the water quality of a water body at Asansol town, West Bengal," Nature Environment and Pollution Technology, vol. 6, no. 2, pp. 289-292, 2007.

[84] P. Li, J. Wu, H. Qian, X. Lyu, and H. Liu, "Origin and assessment of groundwater pollution and associated health risk: a case study in an industrial park, northwest China," Environmental Geochemistry and Health, vol. 36, no. 4, pp. 693-712, 2014.

[85] N. Adimalla, P. Li, and H. Qian, "Evaluation of groundwater contamination for fluoride and nitrate in semi-arid region of Nirmal Province, South India: a special emphasis on human health risk assessment (HHRA)," Human and Ecological Risk Assessment: An International Journal, vol. 25, no. 5, pp. 1107-1124, 2019.

[86] C. N. Mgbenu and J. C. Egbueri, "The hydrogeochemical signatures, quality indices and health risk assessment of water resources in Umunya district, southeast Nigeria," Applied Water Science, vol. 9, no. 1, p. 22, 2019.

[87] V. Duggal, A. Rani, R. Mehra, and V. Balaram, "Risk assessment of metals from groundwater in northeast Rajasthan," Journal of the Geological Society of India, vol. 90, no. 1, pp. 77-84, 2017.

[88] R. Barzegar, A. Asghari Moghaddam, J. Adamowski, and A. H. Nazemi, "Assessing the potential origins and human health risks of trace elements in groundwater: a case study in the Khoy plain, Iran," Environmental Geochemistry and Health, vol. 41, no. 2, pp. 981-1002, 2019.

[89] IRIS, Chemical assessment summary (chromium VI; CASRN 18540-29-9). National Center for Environmental Assessment, Integrated Risk Information System, pp. 1-33, U.S. Environmental Protection Agency, Washington, DC, USA, 1987.

[90] S. Khan, Q. Cao, Y. M. Zheng, Y. Z. Huang, and Y. G. Zhu, "Health risks of heavy metals in contaminated soils and food crops irrigated with wastewater in Beijing, China," Environmental Pollution, vol. 152, no. 3, pp. 686-692, 2008.

[91] H. Su, W. Kang, Y. Xu, and J. Wang, "Assessing groundwater quality and health risks of nitrogen pollution in the Shenfu mining area of Shaanxi Province," Exposure and Health, vol. 10, 2018.

[92] N. Bortey-Sam, S. M. M. Nakayama, Y. Ikenaka et al., "Health risk assessment of heavy metals and metalloid in drinking water from communities near gold mines in Tarkwa, Ghana," Environmental Monitoring and Assessment, vol. 187, no. 7, p. 397, 2015.

[93] B. U. Ukah, J. C. Egbueri, C. O. Unigwe, and O. E. Ubido, "Extent of heavy metals pollution and health risk assessment of groundwater in a densely populated industrial area, Lagos, Nigeria," International Journal of Energy and Water Resources, vol. 3, no. 4, pp. 291-303, 2019.

[94] C. K. Ezugwu, O. S. Onwuka, J. C. Egbueri, C. O. Unigwe, and D. A. Ayejoto, "Multi-criteria approach to water quality and health risk assessments in a rural agricultural province, southeast Nigeria," HydroResearch, vol. 2, no. 1, pp. 40-48, 2019.

[95] V. M. Wagh, D. B. Panaskar, S. V. Mukate, S. K. Gaikwad, A. A. Muley, and A. M. Varade, "Health risk assessment of heavy metal contamination in groundwater of Kadava River Basin, Nashik, India," Modeling Earth Systems and Environment, vol. 4, no. 3, pp. 969-980, 2018.

[96] S. V. Mohan, P. Nithila, and S. J. Reddy, "Estimation of heavy metals in drinking water and development of heavy metal 
pollution index," Journal of Environmental Science and Health Part A: Environmental Science and Engineering and Toxicology, vol. 31, no. 2, pp. 283-289, 1996.

[97] A. M. Odukoya and A. F. Abimbola, "Contamination assessment of surface and groundwater within and around two dumpsites," International journal of Environmental Science and Technology, vol. 7, no. 2, pp. 367-376, 2010.

[98] T. Ruwanpathirana, S. Senanayake, N. Gunawardana et al., "Prevalence and risk factors for impaired kidney function in the district of Anuradhapura, Sri Lanka: a cross-sectional population-representative survey in those at risk of chronic kidney disease of unknown aetiology," BMC Public Health, vol. 19, no. 1, p. 763, 2019.

[99] R. T. Perera, N. Dayanada, S. Botheju et al., "Toxic elements contamination in surface sediments of major tanks in Anuradhapura district; A CKDu endemic district in Sri Lanka," International Journal of Environmental Quality, vol. 41, pp. 40-48, 2020.

[100] C. D. Klaassen, J. Liu, and B. A. Diwan, "Metallothionein protection of cadmium toxicity," Toxicology and Applied Pharmacology, vol. 238, no. 3, pp. 215-220, 2009.

[101] R. A. Goyer, "Mechanisms of lead and cadmium nephrotoxicity," Toxicology Letters, vol. 46, pp. 153-162, 1989.

[102] R. P. Wedeen and L. F. Qian, "Chromium-induced kidney disease," Environmental Health Perspectives, vol. 92, pp. 7174, 1991.

[103] M. L. R. Osorio, I. N. P. Maldonado, M. D. D. Campo et al., "Urinary arsenic levels and risk of renal injury in a crosssectional study in open population," Clinical and Translational Investigation, vol. 64, pp. 609-614, 2012.

[104] Y.-M. Hsueh, C.-J. Chung, H.-S. Shiue et al., "Urinary arsenic species and CKD in a Taiwanese population: a case-control study," American Journal of Kidney Diseases, vol. 54, no. 5, pp. 859-870, 2009.

[105] G. F. Nordberg, T. Jin, F. Hong, A. Zhang, J. P. Buchet, and A. Bernard, "Biomarkers of cadmium and arsenic interactions," Toxicology and Applied Pharmacology, vol. 206, no. 2, pp. 191-197, 2005.

[106] H. C. Gonick, "Nephrotoxicity of cadmium and lead," Indian Journal of Medical Research, vol. 128, no. 4, pp. 335-352, 2008.

[107] W. C. Prozialeck and J. R. Edwards, "Mechanisms of cadmium-induced proximal tubule injury: new insights with implications for biomonitoring and therapeutic interventions," Journal of Pharmacology and Experimental Therapeutics, vol. 343, no. 1, pp. 2-12, 2012.

[108] K. A. A. S. Warnakulasuriya, S. Balasuriya, P. A. J. Perera, and L. C. L. Peiris, "Determining optimal levels of fluoride in drinking water for hot, dry climates -a case study in Sri Lanka," Community Dentistry and Oral Epidemiology, vol. 20, no. 6, pp. 364-367, 1992.

[109] V. Saxena and S. Ahmed, "Inferring the chemical parameters for the dissolution of fluoride in groundwater," Environmental Geology, vol. 43, no. 6, pp. 731-736, 2003.

[110] R. van Geldern, A. Baier, H. L. Subert, S. Kowol, L. Balk, and J. A. C. Barth, "Pleistocene paleo-groundwater as a pristine fresh water resource in southern Germany-evidence from stable and radiogenic isotopes," The Science of the Total Environment, vol. 496, pp. 107-115, 2014.

[111] M. A. R. Buzalaf, "Review of fluoride intake and appropriateness of current guidelines," Advances in Dental Research, vol. 29, no. 2, pp. 157-166, 2018.

[112] X. Xiong, J. Liu, W. He et al., "Dose-effect relationship between drinking water fluoride levels and damage to liver and kidney functions in children," Environmental Research, vol. 103, no. 1, pp. 112-116, 2007.

[113] R. Niu, H. Han, Z. Sun et al., "Effects of fluoride exposure on the antioxidative status in the kidneys of offspring mice during the embryonic and suckling phases," Fluoride, vol. 49, no. 1, pp. 5-12, 2016.

[114] C. B. Dissanayake, "Water quality in the dry zone of Sri Lanka - some interesting health aspects," Journal of the National Science Foundation of Sri Lanka, vol. 33, no. 3, pp. 161-168, 2005. 